\title{
A review of offshore wind turbine nacelle: Technical challenges, research and development
}

\author{
Md. Rabiul Islam, Youguang Guo and Jianguo Zhu \\ Centre for Electrical Machines and Power Electronics, University of Technology Sydney \\ P.O. Box 123, Broadway, Ultimo, New South Wales 2007, Australia
}

\begin{abstract}
The turbine nacelle with traditional wind power generation system is heavy, especially in offshore applications due to the large mass of the power frequency step-up transformer operated at 50 or $60 \mathrm{~Hz}$, and copper conductor generator. For example, the weight and volume of a $0.69 / 33 \mathrm{kV} 2.6 \mathrm{MVA}$ transformer are typically in the range of $6-8 \mathrm{t}$ and $5-9 \mathrm{~m}^{3}$, respectively. The weight for a $10 \mathrm{MW}$ direct drive permanent magnet generator is about 300 t. These penalties significantly increase the tower construction, and turbine installation and maintenance costs. The tower cost represents $26 \%$ of the total component cost of the turbine and on average about $20 \%$ of the capital costs are associated with installation. Typical maintenance cost of an offshore wind turbine is about 2.3 cents/kWh, which is $20 \%$ higher than that of an onshore based turbine. As alternative approaches to achieve a compact and lightweight offshore wind turbine nacelle, different concepts have been proposed in recent years, such as step-up-transformer-less system, medium-frequency (in the range of a few $\mathrm{kHz}$ to $\mathrm{MHz}$ ) power transformer-based system, multilevel and modular matrix converter-based system and superconducting generator-based system. This paper aims to review the challenges, current research and development trends, possible future directions of the research to reduce the weight and volume of the nacelle. In addition, a comprehensive review of traditional wind power generation technologies is conducted in this article as well.
\end{abstract}

Keywords:

Offshore wind farm, power generation, research and development, compact and lightweight nacelle 


\section{Contents}

1. Introduction............................................................... 3

2. Offshore wind power generation systems............................... 5

2.1. Constant speed wind power generation systems...................... 5

2.2. Variable speed wind power generation systems...................... 6

2.2.1. Fully-rated converter-based systems.......................... 6

2.2.2. Partially-rated converter-based systems......................... 7

3. Offshore wind power transmission systems.............................. 8

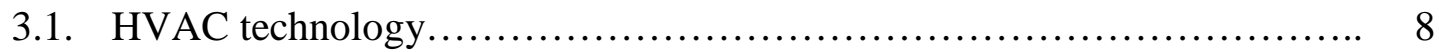

3.2. HVDC technology ........................................... 9

4. Offshore wind turbine generators...................................... 10

4.1 Squirrel cage induction generator (SCIG) .......................... 11

42. Wound rotor synchronous generator (WRSG) ....................... 12

4.3 Permanent magnet synchronous generator (PMSG).................... 12

4.4 Doubly-fed induction generator (DFIG) ............................ 13

4.4.1. Cascaded doubly-fed induction machine......................... 15

4.4.2. Single frame doubly-fed induction machine.................... 16

5. Turbine step-up transformers........................................ 18

6. Turbine component costs................................................ 19

7. Turbine installation costs.............................................. 19

8. Research and development for compact and lightweight nacelle............... 20

8.1 Elimination of turbine step-up transformer........................... 20

8.1.1. Multi-coil generator-based medium-voltage converter............. 21

8.1.2. Multiple generators-based medium-voltage converter............. 25

8.1.3. Medium-frequency magnetic-link-based medium-voltage converter. 25

8.1.4. Matrix converter-based medium-voltage converter............... 26

8.1.5. Medium-voltage DC converter............................... 27

8.2. Medium-frequency transformer-based system......................... 28

8.3. Superconducting generator-based system............................. 29

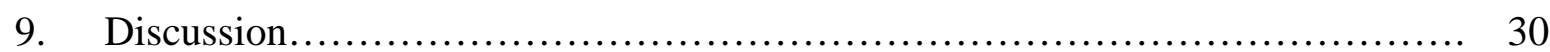

10. Conclusion............................................................. 31

References............................................................. 32 


\section{Introduction}

The energy and environment represent two major areas of global crises, but it is becoming more and more obvious that wind energy may offer solutions to these enormous challenges [1]. Wind energy has continued the worldwide success story as the wind power development is experiencing dramatic growth [2-6]. The cumulative growth of wind turbine installation has directly pushed the wind technology into a more competitive area [7-12]. In this propitious climate, it is therefore essential for scientists and researchers to find the most effective technologies for wind power generation systems.

Wind speed varies continuously as a function of time and height because of changes in the thermal conditions of air masses. The motion of air masses is not only a global phenomenon but also a regional and local phenomenon. The annual peak hours are normally around 2500-3000 in good sites. Wind turbine generator converts wind energy to electricity energy. It follows the energy reservation principle. If $A$ is the cross-sectional area through which the air of velocity $V$ flows, and $\rho$ the air density, the theoretical power $P$ available in a wind stream can be calculated from $[13,14]$

$P=\frac{1}{2} \rho A V^{3}$

Usually offshore winds tend to flow at higher speeds than onshore winds. This allows the turbine to produce more electricity as the possible energy produced from the wind is proportional to the cube of the wind speed. Also unlike onshore wind, offshore breezes can be strong in the afternoon, matching the time when load demands are at peak level. Moreover, wind farms cover large areas of land. The land area covered by a 3.6 MW turbine can be almost $0.37 \mathrm{~km}^{2}$; such that 54 turbines would cover about $20 \mathrm{~km}^{2}$ of land area. Table 1 summarizes the land covered by some offshore wind farms [15-19]. Offshore wind farms save land rental expense which is equivalent to $10-18 \%$ of the total operating and maintenance costs of a wind farm. Therefore, offshore based wind farms have attracted significant attention in recent years. According to statistical data, the cumulative installed capacity of offshore wind farms in 2008, 2010 and 2012 was 1.50, 3.08 and $5.41 \mathrm{GW}$ respectively. The capacity therefore doubled in every two years [20]. Table 2 summarizes the global annually installed capacity of offshore wind farms. It is expected that the global offshore installed capacity will increase to approximately 20 GW by 2015 and rise sharply to 104 GW by 2025. According to the Global Wind Energy Council and Green Peace 
International estimations it is possible to mitigate $20 \%$ of global electricity demand with wind power [21].

Wind turbines are broadly classified into two categories, horizontal axis wind turbines and vertical axis wind turbines. The rotation of main rotor shaft of a horizontal axis wind turbine is in the direction of the wind. The rotor, generator, step-up transformer, and other equipments of a horizontal axis wind turbine are usually placed at the top of the tower. In a vertical axis wind turbine, the generator, transformer, converters and other equipments are usually assembled near the ground. The rotation of rotor shaft of a vertical axis wind turbine is perpendicular to the ground. Due to better aerodynamic performances compared with vertical axis wind turbines, the horizontal axis wind turbines are most commonly used in large-scale offshore wind farms. This paper mainly focuses on the horizontal axis wind turbines.

The turbine nacelle usually houses the generator, power converter, grid side step-up transformer and monitoring and control equipment. The tower provides support to the rotating parts and nacelle (the stationary parts). The nacelle weight of a $5 \mathrm{MW}$ turbine is about 300 t, while the rotor represents only about $120 \mathrm{t}$. Therefore, the tower diameter and strength depend mostly on the weight of the nacelle and expected wind loads. The tower cost accounts for $26 \%$, the largest component, of the total turbine component cost [22].

Table 1

Offshore wind farms data

\begin{tabular}{lllll}
\hline Wind farms & Power capacity (MW) & Distance to shore $(\mathrm{km})$ & Number of turbines & Land covered $\left(\mathrm{km}^{2}\right)$ \\
\hline Barrow & 108 & 7 & 30 & 10.00 \\
Gunfleet Sands & 172 & 7 & 48 & 17.50 \\
Horns Rev & 160 & 15 & 80 & 20.00 \\
Horns Rev 2 & 200 & 27 & 91 & 35.00 \\
Lynn and Inner & 194 & 9 & 54 & 20.00 \\
Ormonde & 150 & 10 & 30 & 8.70 \\
Princess Amalia & 120 & 23 & 60 & 14.00 \\
\hline
\end{tabular}

Table 2

Global offshore wind farms installed capacity

\begin{tabular}{lll}
\hline Year & Annual addition (MW) & Cumulative (MW) \\
\hline 2001 & 51 & 86 \\
2003 & 259 & 515 \\
2005 & 90 & 706 \\
2007 & 318 & 1,117 \\
2009 & 584 & 2,075 \\
2011 & 1,022 & 4,096 \\
\hline
\end{tabular}


The tower is normally held by a heavy foundation to ensure it withstands the overturning moment created from the turbine. The foundation size of a $2.3 \mathrm{MW}$ wind turbine is $314 \mathrm{~m}^{2}$ and the approximate weight is $2000 \mathrm{t}$ or more [23]. In an offshore area, the cost of installation is extremely high. On average, approximately $20 \%$ of the capital costs are associated with installation [24,25]. Therefore, a reduction in mechanical loading represents an enormous saving in terms of tower construction and turbine installation costs.

As the power rating and the distance of the wind farm from the shore increase, the engineering challenges associated with the installation and maintenance of the power generation systems also grows. Recently, many researchers/scientists have begun to focus on a number of areas including: proposing medium-voltage converter to eliminate the step-uptransformer, applying medium-frequency transformers to reduce the weight and volume of step-up-transformers, and superconducting wind generators to reduce the weight and volume of wind turbine generators. These steps are aimed at reducing the weight and volume of the wind power generation systems. The weight and volume reduction of wind turbine power generation system (WTPGS) still needs further investigation because wind power has become one of the main sources of renewable energy for future electricity supply within smart microgrids.

This article presents a technology review of traditional WTPGS, which is focused on the turbine nacelle mainly. A survey of most recent research and development in weight reduction of nacelle in recent years is conducted. The challenges, research trends and possible future directions of the research in lightweight WTPGS for offshore applications are addressed in this paper.

\section{Offshore wind power generation systems}

Wind turbines can operate with either fixed speed or variable speed. The actual rotational speed of a wind turbine is quite low and not fixed in nature. Therefore, the turbine speed must be adjusted to suit the electrical frequency. This can be done in two ways: either with a gearbox or with the number of pole pairs of the generator. The pole pair sets the mechanical speed of the generator with respect to the electrical frequency and the gearbox adjusts the rotor speed of the turbine to the mechanical speed of the generator. The gearbox based system has less lifetime and requires frequent maintenance. The efficiency and armature diameter of an induction machine depend on the number of poles. The increase in the number of poles may decrease the efficiency and increase the magnetizing currents. There are two main types 
of wind power generation systems: (1) the constant speed wind power generation system and (2) the variable speed wind power generation system.

\subsection{Constant speed wind power generation system}

In this system the wind turbine is a fixed speed controlled machine, with a squirrel cage induction generator (SCIG) directly connected to the grid through a power converter and a step-up-transformer, as shown in Fig. 1. Since the SCIG always draws reactive power from the grid, this system uses a capacitor bank for reactive power compensation. It is called the Danish concept and it was very popular in the 1980s.

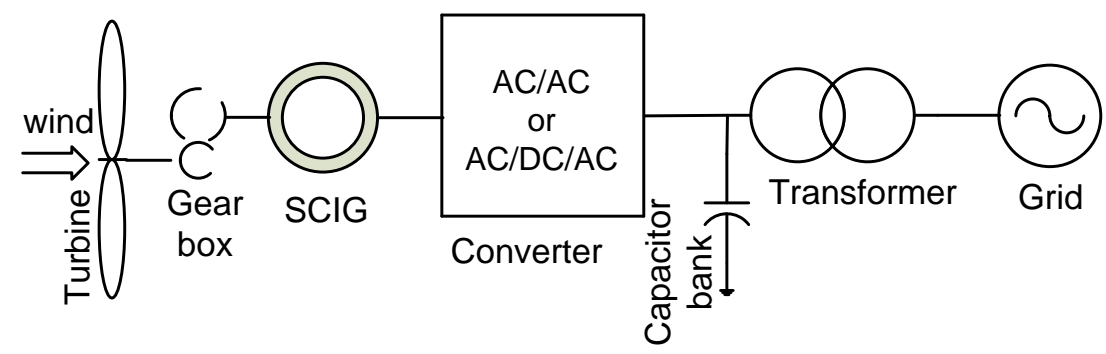

Fig. 1. Constant speed wind power generation system with SCIG.

Because of its robustness, mechanical simplicity and low price, many developing countries have installed this constant speed wind power generation system. However, this system suffers from rotor speed instability. An analysis of rotor speed stability was carried out in [26] to determine whether rotor speed stability could be achieved through the help of reactive power compensation. It was found that the rotor speed stability of a constant speed wind power system could be improved by active stall [27].

\subsection{Variable speed wind power generation systems}

According to the power rating of the converters, the variable speed wind power generation systems can be classified into two groups: (1) the fully-rated converter-based system, and (2) the partially-rated converter-based system.

\subsubsection{Fully-rated converter-based system}

This system consists of a variable speed wind turbine, and the generator connected to the grid through a full scale converter and a step-up-transformer. The converter performs the reactive power compensation and the smoother grid connection. The generator can be excited electrically (wound rotor synchronous generator, WRSG or SCIG) or by a permanent magnet 
(permanent magnet synchronous generator, PMSG). Due to the variable speed operation, it is possible to continuously adapt the rotational speed of the wind turbine according to the wind speed. As a result, the generator speed changes with the variation in wind speed. Due to its low maintenance cost and wide range control capability, the fully-rated power electronics based synchronous generator wind power system has proved to be an attractive solution for offshore applications. There are two types of variable speed wind power generation systems with full rating power converters. The first is the variable speed wind power generation system with the synchronous/induction generator and gearbox, as shown in Fig. 2. The second is the variable speed direct drive (gear less) wind turbine with synchronous generator, as illustrated in Fig. 3, where the synchronous generator can be designed with multiple poles, which implies that there is no need for a gearbox.

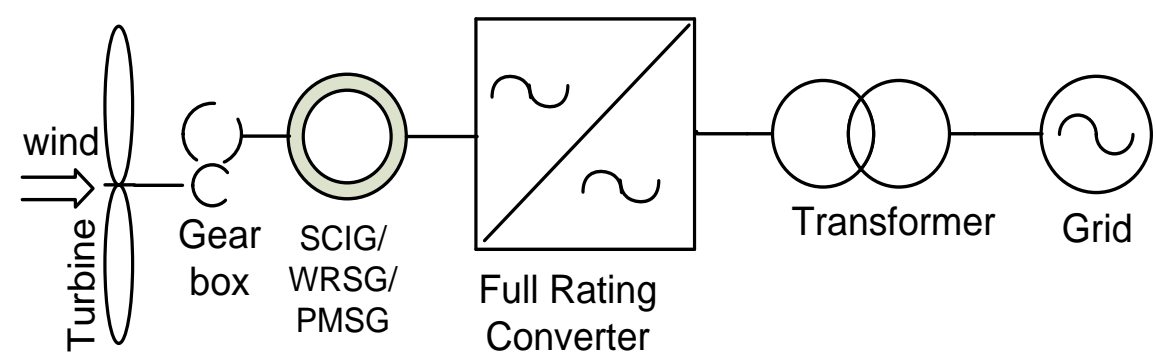

Fig. 2. Variable speed wind power generation system with fully-rated power converter

A development and performance analysis of such a system has been carried out in [28]. In [29], a novel active and reactive power control technique was proposed for a variable speed wind turbine with a fully-rated power electronic conversion system which can maintain the maximum converter efficiency and extract the maximum power. In addition, PMSGs have high torque density and absence of excitation losses.

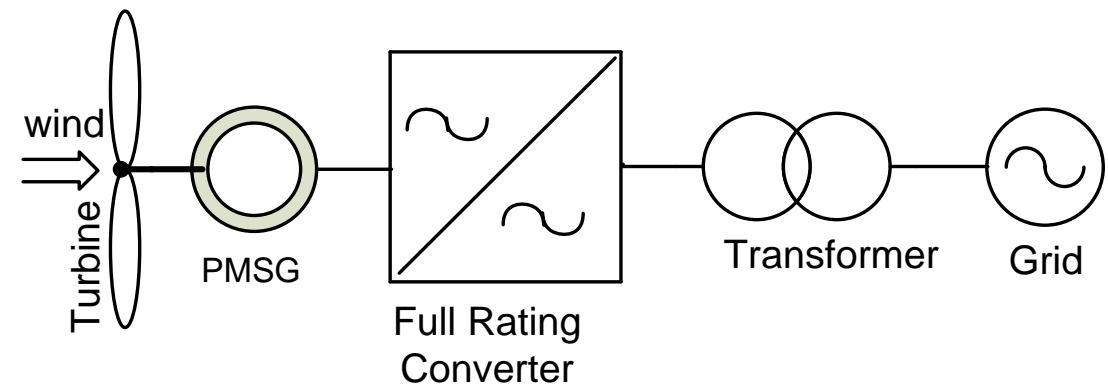

Fig. 3. Variable speed direct drive (gearbox less) wind power generation system with synchronous generator and full rating power converter 


\subsubsection{Partially-rated converter-based system}

This system consists of a variable speed wind turbine with a doubly fed induction generator (DFIG), and a partially-rated power converter (approximately 30\% of generator power) on the rotor circuit, as depicted in Fig. 4. The stator is directly connected to the grid, while a partially rated power converter controls the rotor frequency and the rotor speed. The partially rated converter performs the reactive power compensation and the smoother grid connection. Because the power electronic converter has a power rating of approximately $30 \%$ of the system rated power, this system can not only increase energy transfer efficiency and decrease mechanical stress, but also achieve the decoupling control of the generator's active and reactive powers.

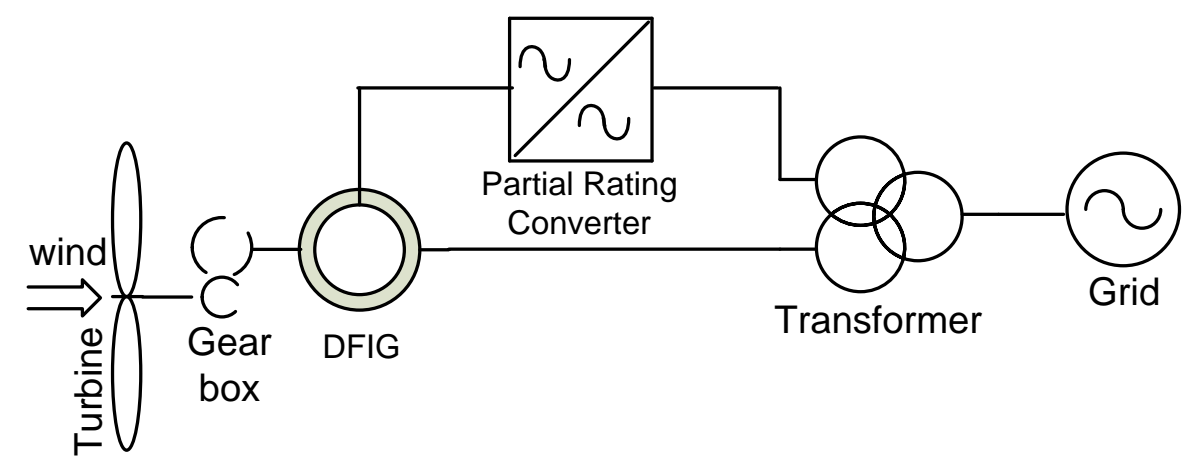

Fig. 4. Variable speed wind power generation system with partial rating power converter

The modelling and simulation of the variable speed wind turbine system with a DFIG has been analyzed in [30,31]. The authors in [32-34] proposed different control techniques. The main drawbacks of the DFIG based system are the use of slip rings and a protection issue in the case of grid faults. The brushless operation of the brushless doubly fed machine (BDFM) has already attracted interest owing to the use of the wind power conversion system. The BDFM maintains all the features of the DFIG but also achieves brushless operation. An analysis, design and control of BDFM have been done in [35]. A slot harmonic BDFM has been designed and analyzed to improve the performance of the BDFM in [36]. The development and performance of a variable speed wind turbine system with a BDFM was analyzed in [37,38] and different control techniques were implemented in [39-41].

\section{Offshore wind power transmission systems}

The existing offshore wind farm consists of on average 50 wind turbines installed in an offshore area (more than $7 \mathrm{~km}$ from the shore) [15-19]. A medium voltage (11-33 kV AC) 
local grid is used to collect the generated power from individual turbines. This collected offshore power is fed to the onshore main grid using a high voltage AC (HVAC) or high voltage DC (HVDC) transmission line.

\subsection{HVAC technology}

Most of the existing offshore wind farms use HVAC technology. The layout of the most common HVAC transmission line-based offshore wind farm is shown in Fig. 5. The variable frequency and variable magnitude power from the generator is converted into fixed frequency and fixed magnitude power using a two-level power converter. To integrate the scattered wind turbine generators into a medium-voltage grid (e.g. 11-33 kV) before the voltage stepup for long distance transmission, a power frequency (50 or $60 \mathrm{~Hz}$ ) step-up transformer is commonly used to step-up the voltage. This offshore wind power is fed to the onshore main grid (132-400 kV) using three-phase underground and submarine HVAC cables through an offshore substation. The Horns Rev offshore wind farm in Denmark (160 MW) uses an 170 $\mathrm{kV}$ AC marine transmission line to transport wind power to an onshore main grid [42]. The charging current of cable capacitance may become too high as the cable length increases and this can greatly reduce the effective power transfer capability. Considering the wind speed and capacitance effect of the HVAC cables, offshore wind turbines are usually installed about 7-30 km from the shore. HVAC systems are established technology and they have a lower cost than the HVDCs when the transmission distance is shorter than $50 \mathrm{~km}$.

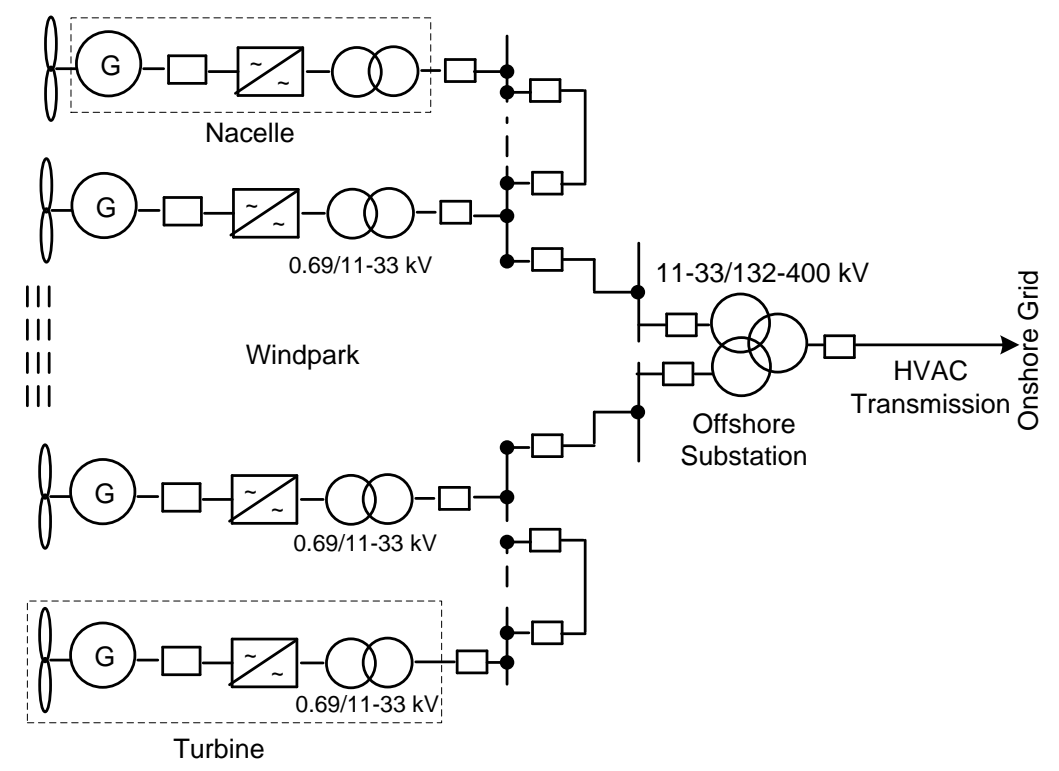

Fig. 5. Layout of the most common HVAC transmission line-based offshore wind farms. 


\subsection{HVDC technology}

The HVDC technology eliminates the cable capacitance effect, thus it is more economically feasible than HVAC technology for power transmission to a distance of above $50 \mathrm{~km}$. The HVDC system provides a considerable cable, installation and maintenance cost reduction, and the fault rate is reduced as well. The development of the classical HVDC technology started in the 1940s. This technology is thyristor-based and well-proven. A thyristor-based power converter is used to convert the HVAC to HVDC.

In the late 1990s, voltage source converter based HVDC (VSC-HVDC) technology was introduced commercially, where IGBTs are used as switching devices. Compared with the classical HVDC solution, the VSC-HVDC solution features compact architecture and provides more controllability, which is important for offshore applications. ASEA Brown Boveri (ABB) and Siemens have been delivering VSC-HVDC systems with trademark of HVDC light and HVDC plus, respectively. The Cross Sound cable is an $150 \mathrm{kV}$ HVDC light underwater cable link between New Haven and Shoreham in U.S.A., with a power of 330 MW and a cable distance of $40 \mathrm{~km}$ [42]. The Basslink interconnector in Australia is the first HVDC interconnector to use the latest Siemens control systems and connects the $500 \mathrm{kV}$ transmission system in Victoria to the $220 \mathrm{kV}$ transmission system in Tasmania. Basslink is a $290 \mathrm{~km}$ undersea cable-based $400 \mathrm{kV}$ DC electricity interconnector, which is rated to transmit 500 MW of energy [42]. The most common layout of the HVDC transmission line-based offshore wind farm is shown in Fig. 6.

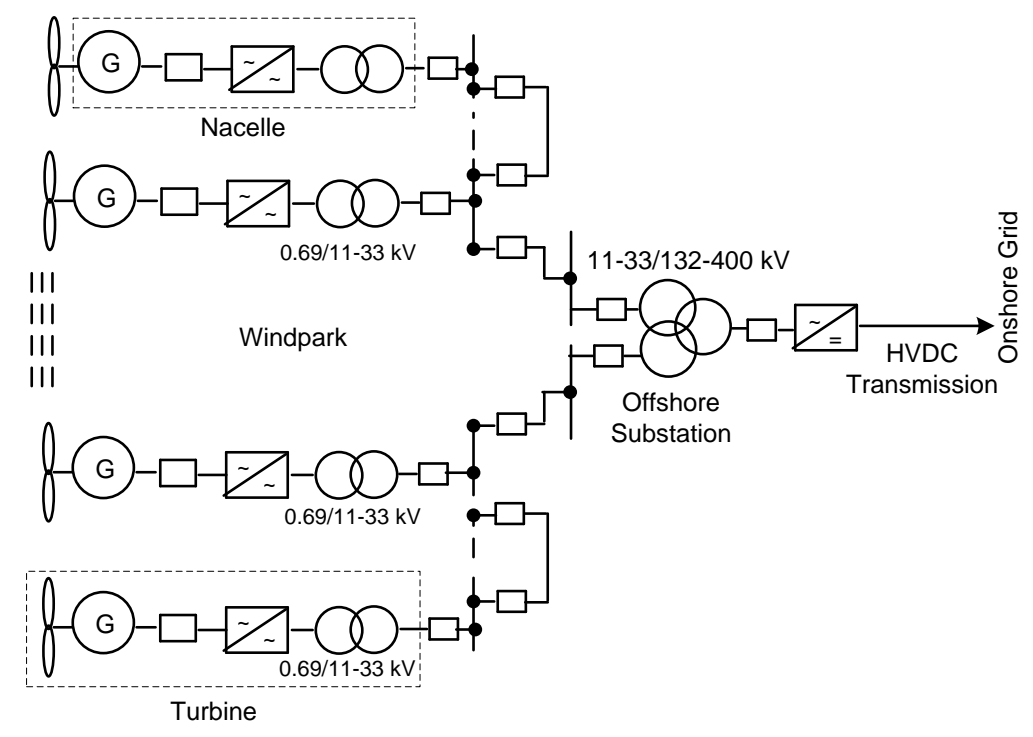


Fig. 6. Layout of the most common HVDC transmission line-based offshore wind farms.

\section{Wind turbine generators}

The generator provides a means of energy conversion between the mechanical torque from the wind rotor turbine, as prime mover, and an electrical load or grid. Large size wind turbines are able to generate more electricity at lower cost compared to the smaller turbines. This is because the set-up costs and maintenance costs do not depend on the size of the machine. Due to this, the output power of today's wind generators has exceeded $7 \mathrm{MW}$. For example, since 2011, Enercon has been producing a wind turbine E-126/7500 with a power capacity of 7.5 MW [43]. Currently, Sway Turbine and Windtec Solutions are developing 10 MW wind turbine generators, which are expected to be commercially available by 2015 [44, 45].

Although the power rating of wind generators has been increasing gradually, the voltage rating of the most common generators is usually in the range of 380-690 V. The exception is Repower which employs $6.6 \mathrm{kV}$ DFIG. Table 3 summarizes the voltage ratings of a few common wind turbine generators [45-49]. As can be seen, the converter voltage level is also in the range of 380-690 $\mathrm{V}$ due to the lower generator voltage rating and the use of two-level converter topology. With exception of the DFIG systems, all the other types of generator systems require full-scale converters.

Table 3

Wind turbine generator voltage rating

\begin{tabular}{llll}
\hline $\begin{array}{l}\text { Turbine power } \\
(\mathrm{MW})\end{array}$ & $\begin{array}{l}\text { Voltage } \\
(\mathrm{V})\end{array}$ & Model & Manufacturer \\
\hline 1.50 & 575 & 1.5 SLE & GE Energy \\
1.65 & 690 & Wt1650 & Windtec \\
2.05 & 575 & MM92 & Repower \\
3.00 & 400 & E-82 E3 & ENERCON \\
5.00 & 690 & Bard 5.0 & Bard Engineering \\
5.50 & 690 & Wt5500 & Windtec \\
10.00 & 690 & SeaTitan & Windtec \\
\hline
\end{tabular}

Basically, a wind turbine can be equipped with induction or synchronous machines. Several types of machines (asynchronous and synchronous) are commonly used in offshore WTPGS. Currently, asynchronous machines dominate wind turbine applications and hold a $70 \%$ share of wind turbine generators. 


\subsection{Squirrel cage induction generator (SCIG)}

Sinovel and Siemens employ SCIG, which is the most common generator used in wind turbines. Because of its mechanical simplicity, high efficiency, low maintenance requirements, small percentage speed changes and low price, the SCIG is used for constant speed wind turbine systems. The induction generator is provided with two windings, one on the stator, and the other on the rotor. The stator winding of the induction machine has two functions. It provides the excitation or magnetisation, and carries the armature or generated current. The rotor winding only carries the armature current. When AC excitation is present, the magnetic field created rotates at a speed determined jointly by the number of poles in the winding and the frequency of the current, i.e. the synchronous speed. If the rotor rotates at a speed other than the synchronous speed, an emf is generated in the rotor winding at a frequency corresponding to the difference between the two speeds, known as the slip frequency. SCIGs have a steep torque speed characteristic and this means that fluctuations in wind power are transmitted directly to the grid. The rotor is a cylinder mounted on a shaft. Internally it contains longitudinal conductive bars (usually made of aluminium or copper) set into grooves and connected together at both ends by shorting rings which form a cage-like shape. The name is derived from the similarity between the rings-and-bars winding and a squirrel cage [50,51]. The machine as a generator is not self excited (it requires magnetizing $\mathrm{kVAR}$ ) and this presents a major problem. The magnetising current is drawn from the power distribution network to which the generator is connected. Capacitor banks connected in parallel to the generator can, if they are in the right size, compensate for the magnetizing or reactive power drawn by the generator. The stator windings of the generator take the magnetising current from the grid, so the full load power factor is relatively low. Also, there is a voltage instability problem at the moment of grid fault and when the fault is cleared. SCIGs can be used both in fixed-speed wind turbines and in full variable speed wind turbines. In variable speed system, the variable frequency power of the machine is converted to fixedfrequency power by using a bidirectional power converter.

\subsection{Wound rotor synchronous generator (WRSG)}

Enercon uses WRSG for wind turbine systems. The synchronous machine is usually built with a rotor which carries the field system and provides a winding excited by the DC. The stator carries a three-phase winding quite similar to that of the induction machine. The rotor 
may have salient poles, or may be cylindrical. Salient poles are more usual in slow speed machines, and may be the most useful version for application to wind turbine generators. The stator windings of WRSGs are connected directly to the grid and hence the rotational speed is strictly fixed by the frequency of the supply grid. The rotor winding is excited with a direct current using slip rings and brushes or with a brushless exciter with a rotating rectifier. Unlike the induction generator, the synchronous generator does not need any further reactive power compensation system. The rotor winding, through which the direct current flows, generates the excitation field, which rotates at the synchronous speed [50,51]. The speed of the synchronous generator is determined by the frequency of the rotating field and by the number of pole pairs of the rotor. But the price that has to be paid for such a gearless design is a large and heavy generator and a full-scale power converter that has to handle the full power of the system. It may be used, at a constant speed, and fixed to the net frequency with consideration of the drive train dependencies and synchronization at start-up. The WRSG may also be applied using a full power inverter, with the option of variable speed operation. In all cases, it is necessary to excite the rotor winding with the DC, using slip rings and brushes, or a brush-less exciter employing a rotating rectifier.

\subsection{Permanent magnet synchronous generator (PMSG)}

GE energy, Vestas, Gamesa, Siemens and Goldwind employ PMSGs. The stator of PMSGs is wound, and the rotor is provided with a permanent magnet pole system and may have salient poles or may be cylindrical. Typical low-speed synchronous machines are of the salient-pole type and feature many poles. If a synchronous generator has an appropriate number of poles (a multi-pole PMSG) it can be used as direct-drive system. The most common types are the radial flux machine, the axial flux machine and the transversal flux machine. In the PMSG machine, the efficiency is higher than that in the induction machine, as the excitation is provided without any energy supply. However, the materials used for producing permanent magnets are expensive, and they are difficult to manufacture. Additionally, the use of PM excitation requires the use of a full scale power converter in order to adjust the voltage and frequency of generation to the voltage and the frequency of transmission, respectively, which in turn, increases the system cost. However, the benefit is that the power can be generated at any speed so as to fit the current wind conditions. Maintenance is generally restricted to bearing lubrication only [50,51]. A major problem is the necessity of maintaining the rotor temperature below the maximum operating temperature 
of the magnet, which may be limited by the Curie point of the magnetic material, and also by the thermal properties of the binding material in the case of powder metallurgy composites. Also, the synchronous nature of the operation causes problems in relation to start-up, synchronisation, and voltage regulation.

\subsection{Doubly-fed induction generator (DFIG)}

Repower has been developing wind turbine using DFIG. Only slip power losses set the limit for the rotor speed of an induction machine if it is allowed to vary the rotor speed. When the slip power losses are high, the efficiency of the machine becomes low. To regulate the rotor speed beyond this limit and reduce the slip power loss it is essential to doubly excite the stator and rotor windings. All electric machines can be categorized as either singly-fed, with one winding set that actively participates in the energy conversion process or doubly-fed, with two active winding sets. DFIG is based on an induction generator with a multiphase wound rotor and a multiphase slip ring assembly with brushes for access to the rotor windings. The principle of the DFIG is that rotor windings are connected to the grid via slip rings and a converter that controls both the rotor and the grid currents. Thus rotor frequency can freely differ from the grid frequency. By using the converter to control the rotor currents, it is possible to adjust the active and reactive power fed to the grid from the stator independently of the generator's turning speed. The control principle used is either the twoaxis current vector control or direct torque control (DTC). The doubly-fed generator rotors are typically wound by 2 to 3 times the number of turns of the stator. This means that the rotor voltages will be higher and the currents correspondingly lower [52]. Thus in the typical $\pm 30 \%$ operational speed range around the synchronous speed, the rated current of the converter is lower which leads to the lower cost of the converter. When the rotor moves faster than the rotating magnetic field from the stator, the stator magnetic field induces a strong current in the rotor. The faster the rotor rotates, the more the power will be transferred as an electromagnetic force to the stator, and converted in turn to electricity which is then fed into the electrical grid. The speed of the generator will vary with the turning force applied to its rotor. The percentage difference between this speed and the synchronous speed is called the generator's slip, which sets the frequency of the generated voltage [52]. The schematic diagram of DFIG is illustrated in Fig. 7 [53]. DFIG can be operated both in motor and 
generator operations with a rotor speed, $\omega_{r}$ around the synchronous speed $\omega_{1}$. The speedtorque characteristics of the DFIG are shown in Fig. 8 [53].

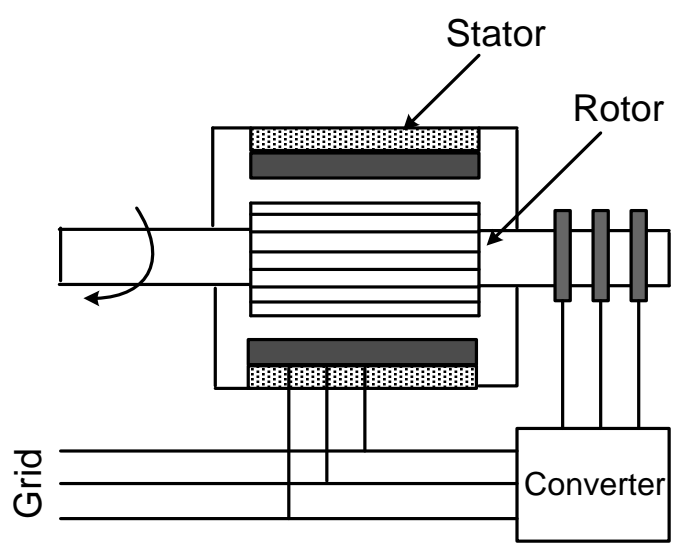

Fig. 7. Principle of DFIG

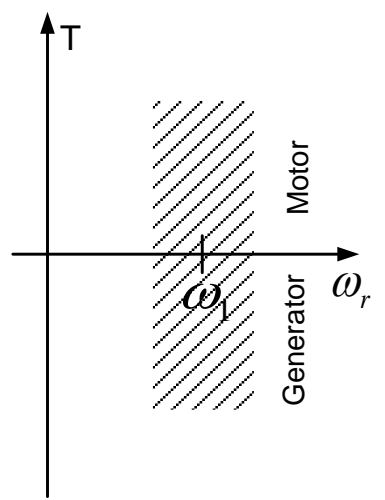

Fig. 8. Speed-torque characteristics of DFIG

Because the losses in the converter circuit depend on the current through the valves, it is important to have an appropriate ratio of stator to rotor turns of the DFIG that can minimize the rotor current without exceeding the maximum available rotor voltage. In summary, a doubly fed induction machine is a wound-rotor doubly-fed electric machine and it has several advantages over a conventional induction machine in wind power applications. Firstly, as the rotor circuit is controlled by a power electronic converter, the induction generator is able to both import and export reactive power. This has important consequences for power system stability and allows the machine to support the grid during severe voltage disturbances (e.g. low voltage ride through, LVRT). Secondly, the control of the rotor voltages and currents enables the induction machine to remain synchronized with the grid while the wind turbine speed varies. 
To overcome the drawbacks of DFIG, more attention needs to be focused on other types of DFIG, such as a cascaded doubly fed induction machine, and single frame doubly fed induction machine.

\subsubsection{Cascaded doubly-fed induction machine}

Compared to a variable speed singly-fed machine arrangement with a cage induction machine, the single doubly-fed induction machine (SDFM) has the advantage of a reduced power converter rating, which is related to the desired speed range. Nevertheless, it still has a drawback: the SDFM has slip-rings and brushes on the rotor side, which are subject to maintenance and additional costs. The cascaded doubly-fed induction machine consists of two doubly-fed induction machines that are connected mechanically through the rotor and electrically through the stator circuits as shown in Fig. 9. The stator circuit of one of the machines is directly connected to the grid while the other machine's stator is connected via a converter to the grid. Since the rotor voltages of both machines are equal, it is possible to control the induction machine that is directly connected to the grid with the other induction machine. It is possible to achieve decoupled control of active and reactive power of the cascaded doubly-fed induction machine in a manner similar to the doubly-fed induction machine [54]. Since the two rotors have a stiff mechanical coupling, no brushes are needed for the slip-ring connection which can eliminate the drawback of SDFM. But due to a large amount of windings, the losses are expected to be higher than that for a standard doubly-fed induction machine of a comparable rating. In the past century, this type of concept has been continuously improved. In 1907, Hunt [55] conducted a remarkable evaluation of the cascade connection concept in a single machine. Further developments were made to the stator and rotor designs by Creedy in 1921 [56]. In 1966, Smith [57] proposed the concept of nonlinking of stator fields of cascade induction machines by spatial separation. A significant contribution to the design of the self-cascaded machine was demonstrated by Broadway and Burbridge in 1970 [58]. The control principle of the cascaded machine was proposed in 1983 by Shibata, et al. [59]. 


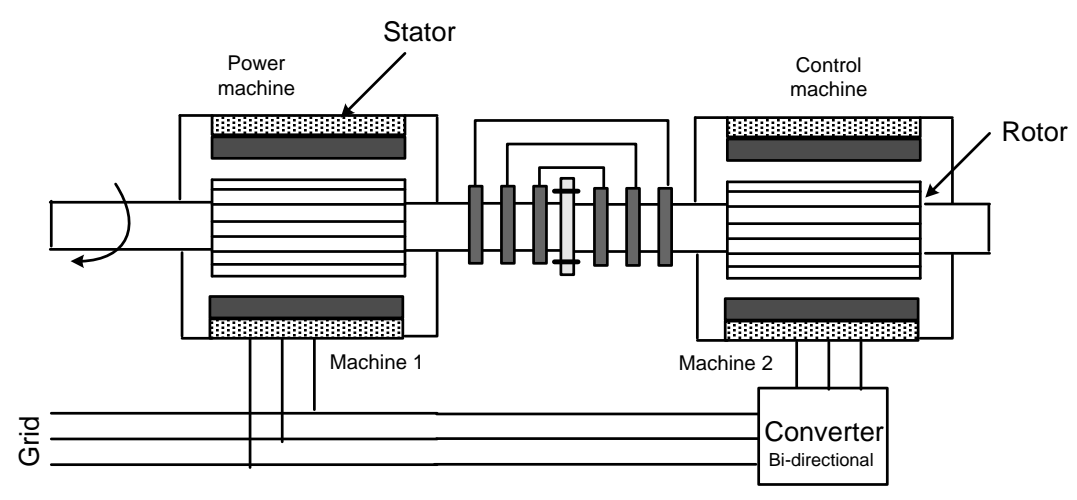

Fig. 9. CDFM arrangement

\subsubsection{Single frame doubly-fed induction machine}

The brushless double fed machine is an induction machine with two sets of symmetrical AC windings in the stator. One winding is for the power and the other for the control. To avoid a direct transformer coupling between the two stator windings, they cannot have the same number of pole pairs. Furthermore, to avoid unbalanced magnetic pull on the rotor, the difference between the pole pairs must be greater than one. The number of poles in the rotor must equal the sum of the number of poles in the two stator windings. In the arrangement, as shown in Figs. 10 and 11 [38,53], one winding, the power winding, which is connected directly to the mains or grid, has a pole-pair number of $P_{p}$ and a frequency of $f_{p}$. The other winding, the control winding, which is supplied with variable voltage at variable frequency from a converter connected to the mains or grid, has a pole-pair number of $P_{c}$ and a frequency of $f_{c}$. At running, there are two rotating magnetic fields in the machine which induce electrical potential to generate current. The rotational speed, $n_{r}$ of BDFM can be calculated from [60]

$$
n_{r}=\frac{60\left(f_{p} \pm f_{c}\right)}{P_{p}+P_{c}}
$$

The "+" operation symbol is used if the electrical source phase sequence of power winding is the same as that of control winding or the “-” symbol is used. For the above relation it is clear that the machine speed is a function of the frequency of the power winding and the frequency of control winding. In the BDFM-based wind power generation system, the variable speed constant frequency power generation can be achieved by adjusting the frequency $f_{c}$ of control winding to a different wind speed. 


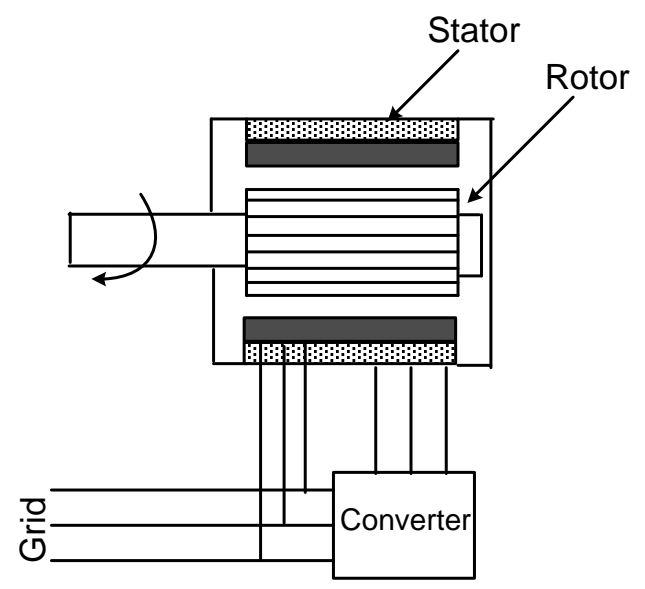

Fig. 10. Layout of the BDFM

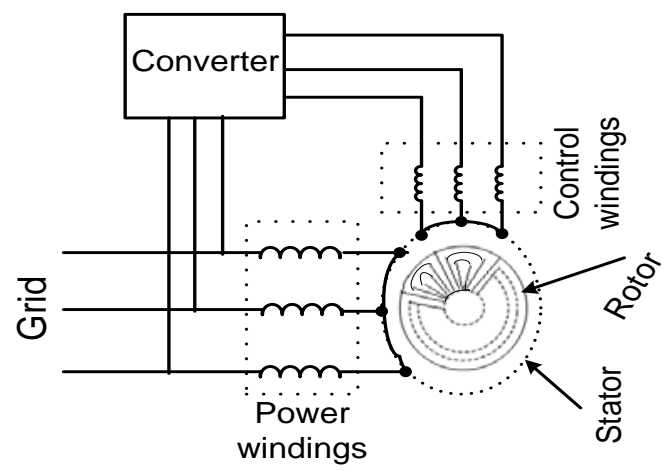

Fig. 11. Equivalent circuit layout of the BDFM

In 1989, the authors in [61] developed the dynamic model of BDFM. An investigation on the effects of various design strategies and a characterization of the BDFM was done in 1990 $[62,63]$. By using direct mathematical transformation, a two-axis model of cage-rotor BDFM was proposed in [64] and the simulation results were also published in [65]. The design of the BDFM is complicated due to the complexities of determining the overall electric loading and magnetic loading and dividing them between the two stator windings. In order to overcome the direct coupling, the two stator windings should have different pole numbers. Now it is common to use two separate windings in the stator [66-68]. To improve the performance many concepts are developed by optimizing the machine structure (mainly on stator) [69-71]. The rotor of the BDFM is specially designed to couple both stator fields and the machine performance is highly dependent on the structure of rotor windings. The switching efficiency of the magnetic poles of the BDFM is determined by the rotor structure, and hence a special rotor structure is essential to improve the switching efficiency. Multiform rotor structures were studied by the scholars for the optimization of the rotor structure [72-75]. 


\section{Turbine step-up transformers}

Power ratings of 2-5 MW per turbine are becoming common for offshore wind farms, where the voltage level of the wind generator is usually in the range of 380-690 V [15-19]. To integrate the scattered wind turbine generators into a medium-voltage grid before the voltage step-up for long distance transmission, a step-up transformer is commonly used to step-up the voltage. In an offshore wind turbine generation system, this transformer is usually installed inside the nacelle together with other equipment, such as the generator and power converter at a height of about 80 meters.

Several vendors have been developing special transformers for wind turbine generator systems aimed at reducing the size and weight. ABB has been delivering worldwide vacuum cast coil transformers and liquid-filled transformers for offshore wind farm applications. Cast coil dry type transformers are non-flamable and moisture proof. They feature a solid isolation system which is discharge free. The volume and weight of a 2.5 MVA vacuum cast coil transformer are about $8.5 \mathrm{~m}^{3}$ and $6200 \mathrm{~kg}$, respectively and no-load and full-load losses are $5.8 \mathrm{~kW}$ and $25 \mathrm{~kW}$ respectively [76]. However, dry type transformers can be sensitive to water, micro-cracks, temperature variations, and pollution which can block cooling ducts. A liquid-filled 2 MVA transformer is about $5.7 \mathrm{~m}^{3}$ in volume and $4530 \mathrm{~kg}$ in weight with 870 $\mathrm{kg}$ of liquid for cooling and insulation [77]. The no-load and full-load losses are approximately $3.2 \mathrm{~kW}$ and $21 \mathrm{~kW}$ respectively. Pauwels developed the SLIM transformer which is compact in size and features that no-load losses are typically half those of the drytype transformer. A 33/0.69 kV, 2.6 MVA SLIM transformer has a no-load loss of $2.6 \mathrm{~kW}$ and a full-load loss of $22.5 \mathrm{~kW}$ [25]. The volume and weight of a 20/0.69 kV, 2.3 MVA BioSLIM transformer are about $4 \mathrm{~m}^{3}$ and $5040 \mathrm{~kg}$, respectively [78]. The use of about $900 \mathrm{~kg}$ or more silicone fluid as the coolant and insulator in these transformers ensures a high degree of fire safety; the flash point of mineral-oil dielectric is about $150^{\circ} \mathrm{C}$, whereas the silicone fluid's flash point is about $360^{\circ} \mathrm{C}$.

This heavy and large size step-up-transformer significantly increases the weight and volume of the nacelle as well as increasing the mechanical stress of the tower. These penalties are critical in offshore applications, where the cost of installation and regular maintenance is extremely high. For example, an offshore wind farm requires about $20 \%$ higher operating and maintenance cost compared with an onshore farm. 


\section{Turbine component costs}

On average, more than 220 tons steel is required to build a 5 MW turbine tower and about 130 tons steel is required to build a 2 MW turbine tower. Nowadays this has become a critical issue as the turbine size increases. The typical weights of the different major parts of the 2 to $5 \mathrm{MW}$ offshore wind turbines are summarized in Table $4[25,79]$.

\section{Table 4}

Weight of commonly used offshore wind turbine

\begin{tabular}{lllll}
\hline Turbine & $\begin{array}{l}\text { Capacity } \\
\text { (MW) }\end{array}$ & $\begin{array}{l}\text { Tower } \\
\text { (tons) }\end{array}$ & $\begin{array}{l}\text { Rotor } \\
\text { (tons) }\end{array}$ & $\begin{array}{l}\text { Nacelle } \\
\text { (tons) }\end{array}$ \\
\hline Vestas V80 & 2.00 & 130 & 37 & 67 \\
Siemens 2.3-93 & 2.30 & 134 & 60 & 82 \\
Siemens 3.6-107 & 3.60 & 180 & 95 & 125 \\
Repower 5M & 5.00 & 225 & 120 & 300 \\
\hline
\end{tabular}

At current pricing levels, a 5 MW offshore wind turbine should cost about 18.5 million USD and the same power rated onshore wind turbine would be about 10 million USD [80]. The tower cost accounts for $26 \%$, the largest component, of the total turbine component cost, whereas the generator and power converter represents only $3 \%$ and $5 \%$ of the total cost, respectively [22]. The turbine blade cost represents 22\%, the second largest component, of the total turbine component cost. In a gearbox based system, the gearbox accounts for $13 \%$ of the total cost. The bulky and heavy traditional components add significantly to the mechanical loading of the tower although new designs aim to reduce the component size and weight. Reduction of mechanical loading means enormous saving of tower construction cost.

\section{Turbine installation cost}

The costs associated with developing, engineering, equipment procurement and delivering/constructing an offshore wind farm can be defined as the total capital cost. According to an energy research group report the first two activities contribute about $10 \%$ and the third contributes $40-60 \%$ of the total capital cost [79]. The total capital cost was about 2.2 million USD per megawatt in 2005 and almost 3.5 million USD per megawatt in 2009. The estimated capital cost of a few offshore wind farms is summarized in Table 5. Construction involves fabricating, assembling and installation and contributes $20-40 \%$ of the total cost. The installation cost is a fractional component of capital cost and it is estimated at 10 to $30 \%$ of the total cost as available in the existing literature [23,14]. On average, the turbine installation cost was 0.42 million USD per megawatt in 2005 and 0.75 million USD 
per megawatt in 2010. The weight reduction of the wind turbine can reduce the installation cost as well as the total capital cost of offshore wind farms.

Table 5

Capital costs of offshore wind farms

\begin{tabular}{lccccc}
\hline Wind farm & $\begin{array}{c}\text { Capacity } \\
\text { (MW) }\end{array}$ & $\begin{array}{c}\text { Cost (Million) } \\
\text { Cost }\end{array}$ & Currency & Cost/MW* & $\begin{array}{l}\text { Year } \\
\text { online }\end{array}$ \\
\hline Kentish F. & 90 & 105 & GBP & 2.14 & 2005 \\
OWEZ & 108 & 217 & Euro & 2.54 & 2006 \\
Lillgrund & 110 & 1800 & SEK & 2.38 & 2007 \\
Robin Rigg & 180 & 420 & Euro & 3.62 & 2008 \\
Rhyl Flats & 90 & 190 & GBP & 3.47 & 2009 \\
Gunfleet S. & 172 & 3900 & DKK & 3.75 & 2010 \\
\hline
\end{tabular}

* Approximate cost in million USD/MW; exchange rates are chosen as respective years

\section{Research and development for compact and lightweight wind turbine nacelle}

Nowadays in offshore wind farms, it is common to assemble the nacelle with other equipment such as blade and spinner, at a height of about 80 meters. The nacelle houses mainly gearbox, mechanical brakes, hydraulic cooling devices, generator, power converter, and transformer. This paper only covers the nacelle section of the wind turbines, i.e. research and development on generators, power converters and step-up-transformers to reduce the weight and volume of the WTPGS.

\subsection{Elimination of turbine step-up transformer}

Elimination of heavy and large grid side step-up-transformer from the nacelle means significant reduction of weight and size of WTPGS. Medium-voltage power electronic converters like multilevel converter topology and modular matrix converter topology have been gaining the popularity to eliminate the grid side step-up-transformers in recent years.

\subsubsection{Multi-coil generator based medium voltage converter}

With the arrival of new high-power semiconductor devices, new power converter structures are conceived to meet the needs of future medium or high-voltage converter systems. In this highly active area, neutral point clamped (NPC), flying capacitor (FC) and modular multilevel cascaded (MMC) converter topologies and circuits as shown in Fig. 12 have found their application in low voltage systems [81,82]. 


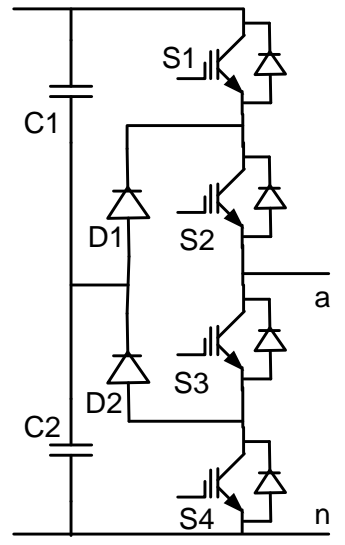

(a)

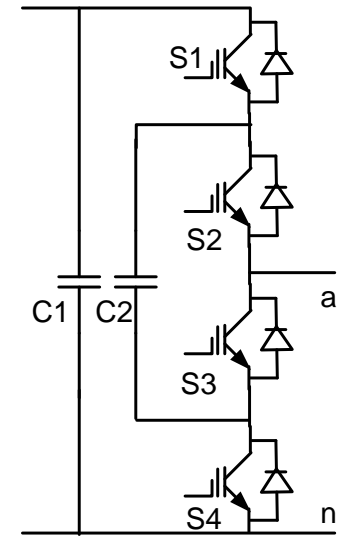

(b)

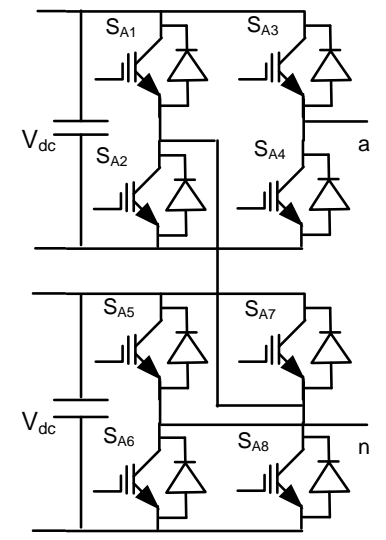

(c)

Fig. 12. Single-phase converter circuit diagram: (a) 3-level NPC, (b) 3-level FC, and (c) 5-level MMC

For medium or high-voltage applications, however, the selection of multilevel converter topology is very critical. The component numbers of NPC and FC converters scale quadratically with the number of levels. Also, the voltage balancing becomes a significant problem for high-level numbers [83]. The component numbers of the MMC converter scales linearly with the number of levels and the individual modules are identical and completely modular in construction and hence enable high-level number attainability. High-level converter implies elimination of power transformer and lower total harmonic distortion (THD) with lower switching frequency, eliminating the output filters and reducing running cost [84]. High-level number attainability also allows lower level of DC-link voltage requirement for each H-bridge cell that eliminates boosters. Moreover, in the case of a fault in one of these modules, it is possible to replace it quickly and easily. A comparative study among these three multilevel converter topologies is carried out as summarized in Table 6 . Based on performance, complexity and cost, the overall comparison is carried out as summarized in Table 7. The MMC topology has gained the lowest index value, which means this topology is the feasible choice for medium-voltage converter applications. The high number of levels means that medium-voltage attainability is possible with lower-voltage devices to connect the wind turbine to the medium-voltage network directly and also possibility to improve the output power quality. The component number and control complexity increases linearly with the increase of level number. Therefore, the optimum selection of number of inverter level is important for best performance/cost ratio of the WTPGS. Different converters (9-21 levels) are analyzed for transformer-less $11 \mathrm{kV}$ grid connections, where the generator output voltage is considered at $690 \mathrm{~V}$. Table 8 illustrates the summary of the converters. Final comparison with these seven different converters is 
summarized in Table 9. The 19-level converter has gained the lowest index value, which means this topology is the feasible choice for $11 \mathrm{kV}$ network applications.

Table 6

Cost and performance of different converters (3-phase, $11 \mathrm{kV}, 250 \mathrm{~A}$ )

\begin{tabular}{llllllll}
\hline \multirow{2}{*}{$\begin{array}{l}\text { Converter } \\
\text { topology }\end{array}$} & \multicolumn{3}{c}{ 5-level } & & \multicolumn{3}{c}{ 11-level } \\
\cline { 2 - 3 } \cline { 7 - 8 } \cline { 7 - 8 } IGBTs & NPC & FC & MMC & & NPC & FC & MMC \\
Diodes & 48 & 48 & 48 & & 60 & 60 & 60 \\
Capacitors & 36 & --- & --- & & 270 & --- & --- \\
Total comp. & 84 & 66 & 48 & & 330 & 195 & 60 \\
ALOs & --- & 18 & -- & & --- & 135 & -- \\
Total cost (AU\$) & 90962 & 113131 & 82027 & & 115663 & 125359 & 82159 \\
THD (\%) & 17.28 & 17.80 & 18.13 & & 7.07 & 7.28 & 7.70 \\
\hline
\end{tabular}

* Number of arithmetic and logic operations (ALOs) is used to calculate the complexity of control circuit

Table 7

Overall comparison of different converters (3-phase, $11 \mathrm{kV}, 250 \mathrm{~A}$ )

\begin{tabular}{llllllll}
\hline \multirow{2}{*}{$\begin{array}{l}\text { Converter } \\
\text { topology }\end{array}$} & \multicolumn{3}{c}{ 5-level } & & \multicolumn{3}{c}{ 11-level } \\
\cline { 2 - 4 } \cline { 6 - 7 } & NPC & FC & MMC & & NPC & FC & MMC \\
\hline Performance & 0.92 & 0.97 & 1.00 & & 0.00 & 0.02 & 0.05 \\
Complexity & 0.00 & 0.00 & 0.12 & & 0.78 & 0.78 & 1.00 \\
Cost & 0.21 & 0.72 & 0.00 & & 0.78 & 1.00 & 0.00 \\
Total index & 1.13 & 1.69 & 1.12 & & 1.56 & 1.80 & 1.05 \\
\hline
\end{tabular}

Table 8

MMC converters comparison (3-phase, $11 \mathrm{kV}, 250 \mathrm{~A})$

\begin{tabular}{llllllll}
\hline Level number & 9 & 11 & 13 & 15 & 17 & 19 & 21 \\
\hline IGBTs & 48 & 60 & 72 & 84 & 96 & 108 & 120 \\
IGBT rating (kV) & 4.5 & 3.3 & 3.3 & 2.5 & 2.5 & 1.7 & 1.7 \\
DVUF $^{*}(\%)$ & 90 & 90 & 75 & 96 & 84 & 99 & 90 \\
THD (\%) & 9.60 & 8.20 & 6.90 & 6.00 & 5.20 & 4.30 & 4.25 \\
Cost (AU\$) & 86400 & 82159 & 98577 & 50400 & 57600 & 36670 & 40744 \\
ALOs & 44 & 55 & 66 & 77 & 88 & 99 & 110 \\
\hline
\end{tabular}

* Device voltage utilization factor (DVUF)

Table 9

Overall comparison of MMC converters (3-phase, 11 kV, 250 A)

\begin{tabular}{llllllll}
\hline Level number & 9 & 11 & 13 & 15 & 17 & 19 & 21 \\
\hline Performance & 1.00 & 0.74 & 0.49 & 0.33 & 0.18 & 0.01 & 0.00 \\
Complexity & 0.00 & 0.17 & 0.34 & 0.50 & 0.67 & 0.83 & 1.00 \\
Cost & 0.80 & 0.73 & 1.00 & 0.22 & 0.33 & 0.00 & 0.06 \\
Total index & 1.80 & 1.64 & 1.83 & 1.05 & 1.18 & 0.84 & 1.06 \\
\hline
\end{tabular}

However, the MMC converter requires multiple-isolated and balanced DC sources that must be balanced as shown in Fig. 13, and therefore its application is not straightforward, 
especially in wind power generation systems. Many researchers have addressed their efforts to proposing special modulation techniques [85], switched DC voltage sources and lowfrequency phase-shifted transformer feeding [86]. The first two approaches do not give an overall solution and the third introduces a complicated three phase heavy and large transformer.

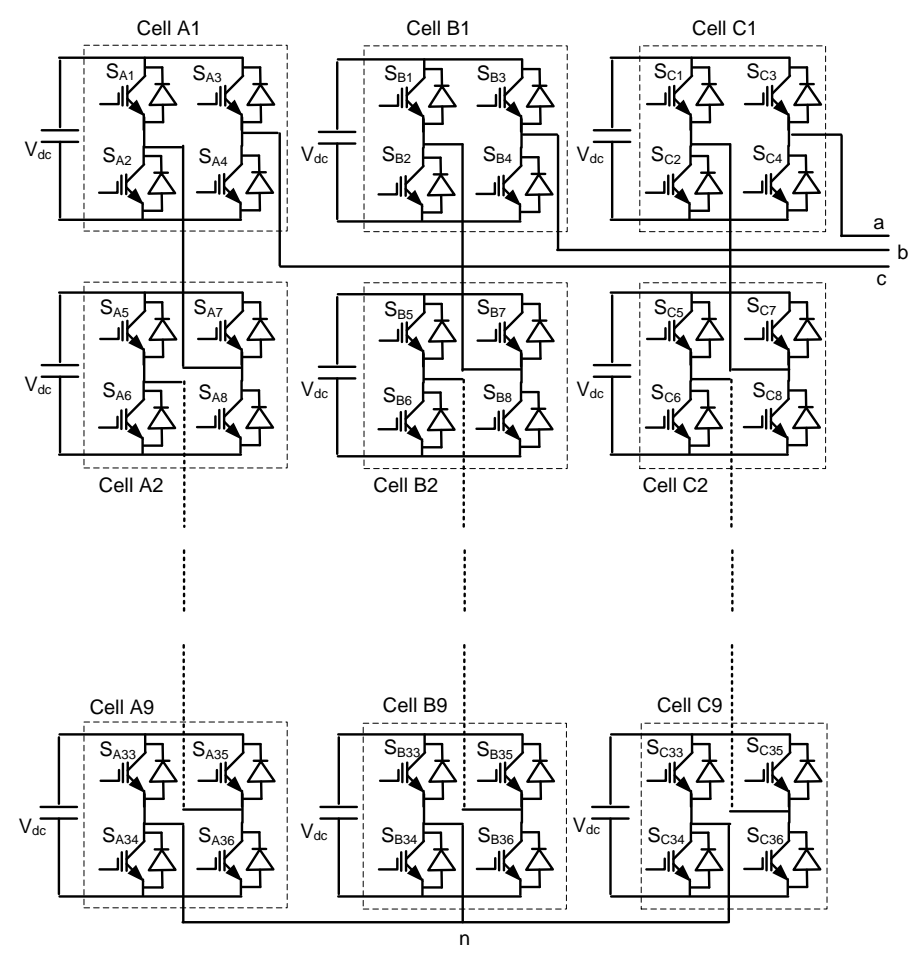

Fig. 13. Three-phase 19-level MMC multilevel converter.

Direct drive ensures lower maintenance cost and complexity by eliminating the single or multiple stage gearboxes (three stage gearboxes are commonly used). Besides the major manufacturers, several newer manufacturers such as Mitsubishi, Leitwind, Harakosan and Vensys are introducing offshore wind turbines based on direct drive PMSGs. A new type of lightweight ironless-stator modular direct drive generator, known as the spoked lightweight machine (SliM) was proposed in 2005 for direct-drive wind turbine power generation systems [87]. This is a permanent magnet generator (PMG) with a large number of magnets placed on the steel rotor rim. Copper coils are accommodated on the non-iron inner stator rim. The ironless stator and gearbox free operation allow a lightweight structure but still require a grid side step-up-transformer. In 2006, a study was carried out to eliminate the grid side step-uptransformer from the SliM-based WTPGS [88]. Pair of generator coils of SliM were used to generate multiple sources for the MMC converter as shown in Fig. 14. A similar converter 
concept was also proposed in [89]. In 2008, an $11 \mathrm{kV}$, 25-level converter with $2.5 \mathrm{~kW}$ modular PMG (72 isolated stator coils) was designed [90]. A multi-coil generator-based wind turbine system is shown in Fig. 15. This multi-winding generator requires a special winding arrangement (which increases the weight and volume) and complicated control strategies. An improved control strategy was proposed and verified on a similar generator converter system [91,92]. The rotor diameter of a low-speed, direct-drive synchronous generator is several times larger than that of a conventional gearbox based high speed generator. Although recently a few manufacturers such as Enercon and Siemens have shown that advanced direct drive turbines have a weight comparable to gearbox based turbines, the direct drive turbines are generally considered to be expensive, heavy and large. The most critical drawback of the multi-coil generator and MMC converter-based wind power generation system is the lack of electrical isolation between the grid and turbine generator.

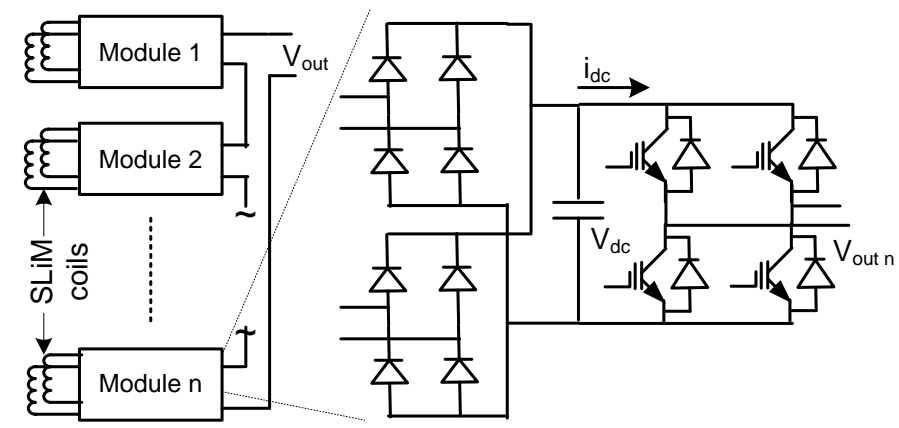

Fig. 14. SliM-based medium-voltage converter topology.

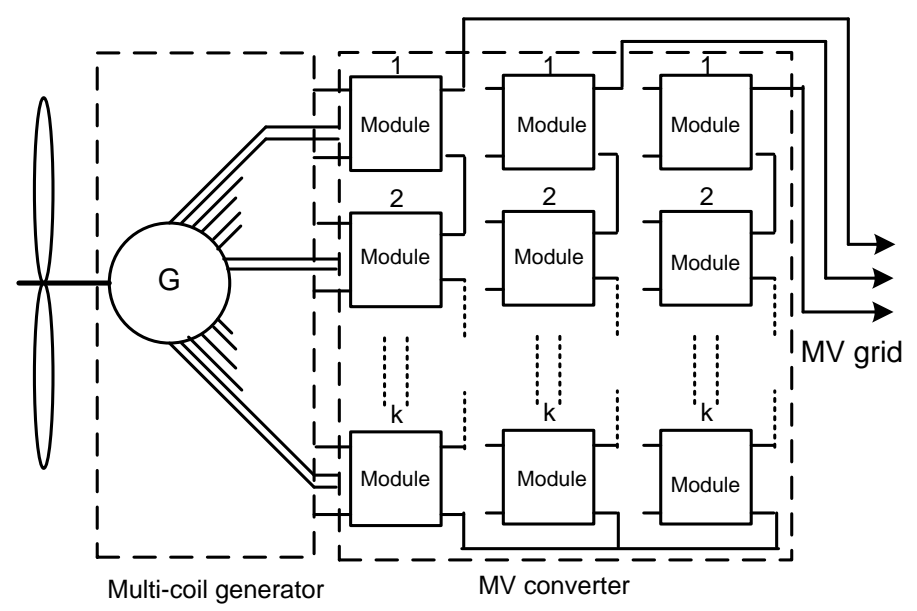

Fig. 15. Multi-coil generator based WTPGS

\subsubsection{Multiple generators-based medium voltage converter}


A transformer-less wind power generation structure with several parallel six phase PMSGs has been proposed in [93], where a few of 6-phase generators are placed in the turbine nacelle. A multiple generators based wind turbine system is shown in Fig. 16. All the generators are driven by the same wind turbine and each stator winding generates an isolated source for an H-bridge inverter cell of the MMC converter. The MMC converter generates medium voltage AC output, which can be connected to the medium-voltage network directly. The proposed structure requires multiple generators, depending on the number of levels of MMC converter. The multiple generators increase the system volume and weight and make the system impractical especially in medium-voltage applications, where a high number of levels is required. Moreover, the grid isolation is the critical issue in the proposed converter system.

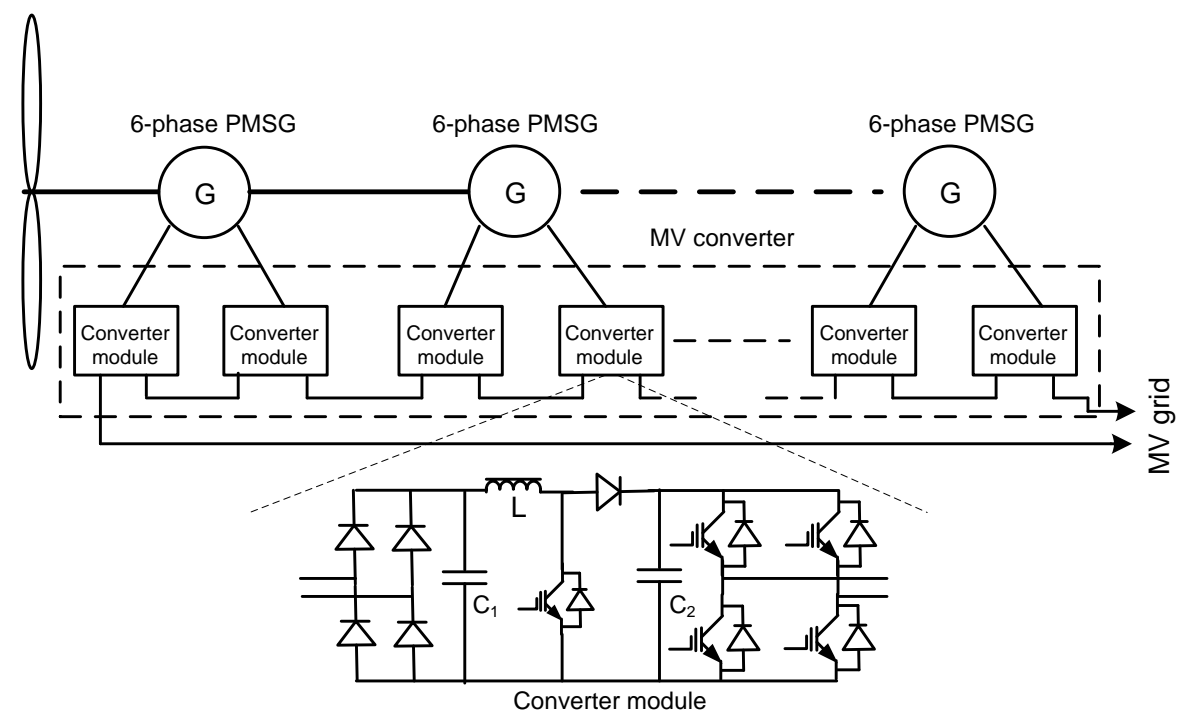

Fig. 16. A multiple generators-based wind turbine system: single-phase layout.

\subsubsection{Medium-frequency magnetic link-based medium-voltage converter}

Compared with the conventional transformers operated at the power frequency, the medium-frequency (in the range of a few $\mathrm{kHz}$ to $\mathrm{MHz}$ ) transformers have much smaller and lighter magnetic cores and windings, and thus much lower costs. A medium-frequency magnetic-link based novel medium-voltage MMC multilevel converter system was proposed as shown in Fig. 17, to eliminate the grid-side step-up-transformer, which is desirable for both onshore and offshore WTPGS [94-96]. In 2013, an amorphous alloy-based mediumfrequency magnetic-link was proposed to generate isolated and balanced multiple dc supplies 
for the MMC converter $[97,98]$. In order to design optimal medium-frequency magnetic-link, the performances of different amorphous alloys were analyzed in [99]. This mediumfrequency magnetic-link-based medium-voltage converter eliminates the grid side step-uptransformer without changing the design of traditional generators. A three-phase mediumvoltage converter-based wind power generation system is shown in Fig. 18. The mediumfrequency magnetic-link medium-voltage converter-based wind turbine system has the following new features compared with the existing similar systems: (1) no requirement for special or multiple generators; (2) an inherent dc-link voltage balance due to common magnetic-link; (3) direct gird connection without using step-up-transformer and line filter; (4) an overall compact and lightweight system; and (5) an inherent minimization of the grid isolation problem through the medium-frequency magnetic-link.

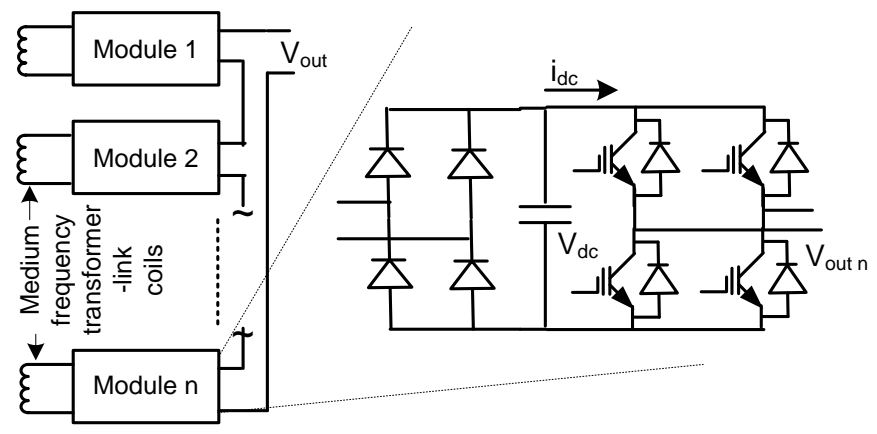

Fig. 17. Medium-frequency magnetic-link-based medium-voltage converter topology: single phase layout.

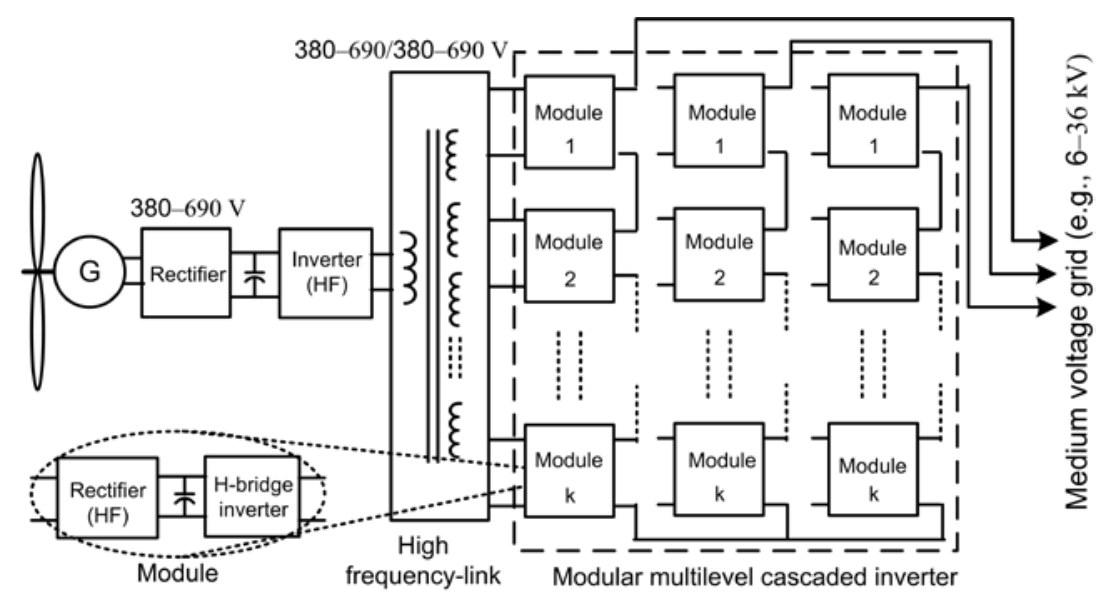

Fig. 18. Detailed layout of medium/high-frequency magnetic-link-based wind power generation system.

\subsubsection{Matrix converter-based medium voltage converter}


The matrix converter (MC) is a unique topology $\mathrm{AC}$ to $\mathrm{AC}$ power converter that eliminates the need for an intermediate DC conversion and the passive reactive filter components associated with this DC-link [100,101]. The converter consists of an array of bidirectional switches positioned at the intersection points of the input and output phases. The output is synthesized by the selective closings and opening of the switches. A combination of MC topology and multilevel converter topology was investigated in [102].

MCs offer the potential for significant size and weight reductions in power converter applications due to the absence of any large energy storage elements, such as DC-link capacitors [103]. Due to this special feature, the MC has attracted considerable attention in recent years [104, 105]. A disadvantage of the MC is the intrinsic limitation of the output voltage; without entering the over-modulation range, the maximum output voltage of the MC is 0.866 times of the input voltage.

A high power MC converter was patented in 1999 [106]. In 2005, an 150 kVA MC was fabricated and tested for electric vehicle applications [107]. In 2007, the first multi-winding phase-shifted transformer based medium voltage multi-modular MC topology was proposed in [108]. The MC topology was implemented commercially in 2008 [109]. In 2011, singlephase output matrix converter (SPMC)-based medium-voltage motor drive system was implemented in [110,111] and its application in wind power system was proposed in [112]. The converter topology is shown in Fig. 19. Split winding PMSG wind turbine generators based modular MC was also investigated in [113] to eliminate the grid side transformer from the wind turbine power generation systems. Although this design does not require special machine, it needs several generators. 


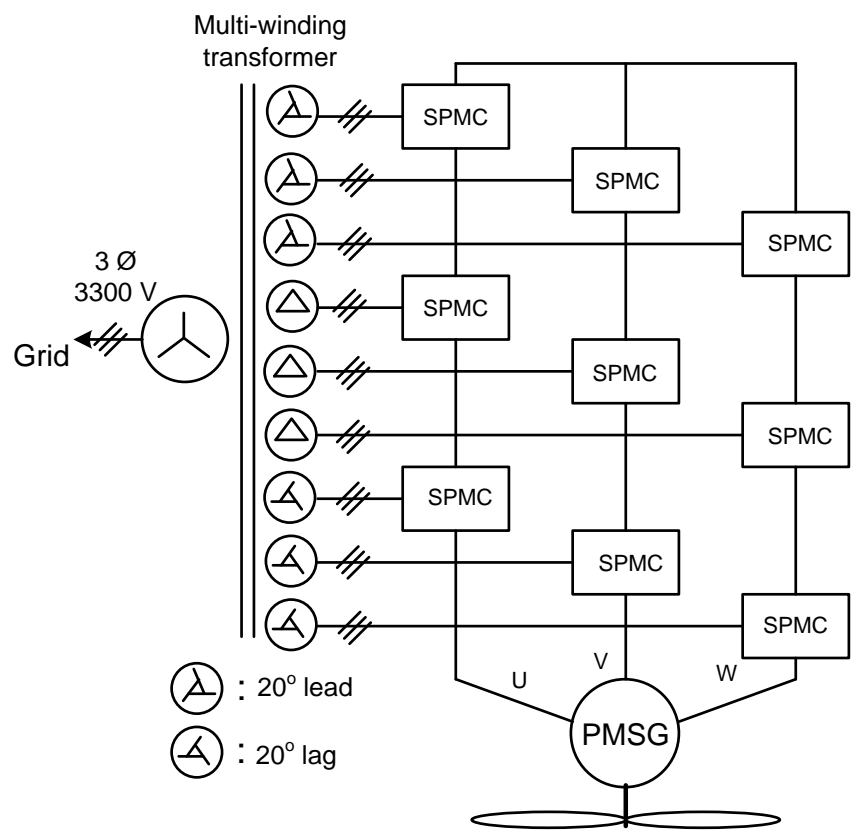

Fig. 19. SPMC-based medium-voltage wind turbine generator system.

\subsubsection{Medium-voltage DC converter}

Recently, a transformer-less generator-converter concept has been introduced for lightweight HVDC WTPGS [114,115]. The iron-less stator generator with several stator segments and modular AC/DC converters was used in the proposed system as portrayed in Fig. 20. In 2012, a minimum weight dual active bridge converter was proposed to reduce the weight of WTPGS [116].

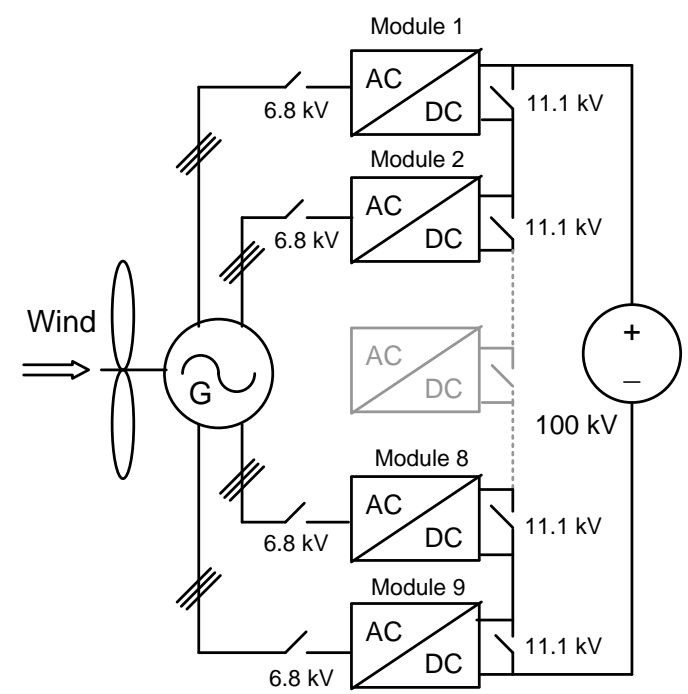

Fig. 20. Wind turbine with segmented stator generator and modular converter. 


\subsection{Medium-frequency transformer-based system}

Increasing the operation frequency can greatly reduce the physical volume of the transformer, which has been widely used in switched mode power supplies. Operated at 1.2 $\mathrm{kHz}$, the weight and size of a $3 \mathrm{MW}$ transformer can be less than $8 \%$ of an equivalent $50 \mathrm{~Hz}$ unit [117]. For high-power applications, a new type of transformer employing new magnetic materials with higher saturation flux density levels and lower core losses, and efficient semiconductor devices with fast switching possibilities, high blocking capabilities, and higher power densities, known as the power electronic transformer, was investigated in [118]. In 2004, an HVDC wind power generation system was introduced [119]. The proposed converter system consists of voltage source converter and cycloconverters connected through medium-frequency transformers. A new HVDC wind farm with medium-frequency transformer was introduced in [117,120] as shown in Fig. 21.

Design considerations of a 3 MW medium-frequency transformer for offshore wind farms were proposed in [121]. A multi-generation turbine and MC-based HVDC system has been proposed in [122]. That proposed system consists of a reduced MC, a high frequency transformer (HFT) and full bridge rectifier as shown in Fig. 22.

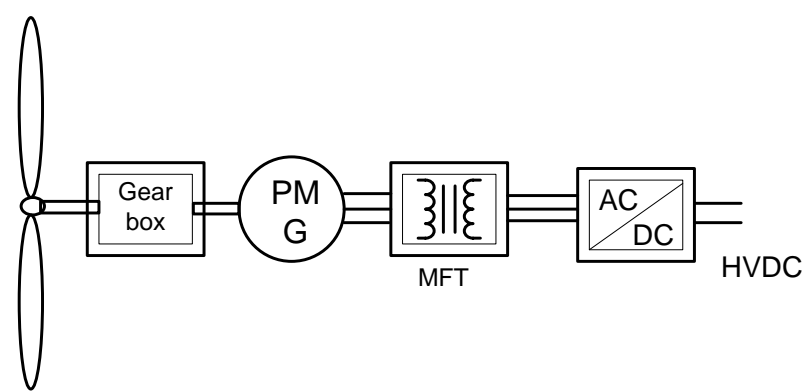

Fig. 21. Wind turbine with PM generator and MFT.

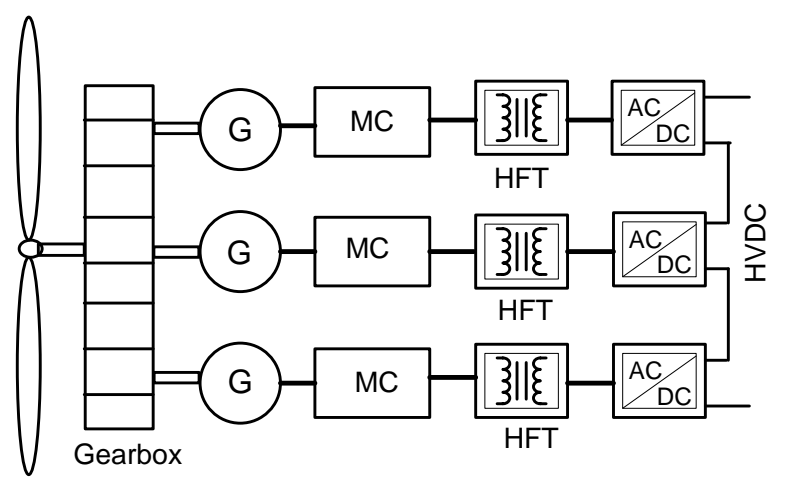

Fig. 22. Wind turbine with MC and multi-generation system. 


\subsection{Superconducting generator-based system}

Superconductors are materials which carry almost loss-free electrical currents, when cooled down below their critical temperatures. Low temperature superconductors have found their market in magnetic resonance imaging (MRI) diagnostics systems and in high energy physics laboratories. From 1975 to 1979 a detailed conceptual design study of 300 and 1200 MVA steam turbine generators utilizing superconducting field windings was carried out in $[123,124]$. The high temperature superconductor (HTS) materials were discovered in 1986 by International Business Machines (IBM) researchers and then gradually improved with a concomitant reduction in cost.

The current densities of the superconductors are over 100 times higher than those in conventional copper conductors. Therefore, a superconductor based compact and lightweight generator may reduce the weight of wind turbine power generation systems. The optimum weight for a $10 \mathrm{MW}$ direct drive PMG is about $300 \mathrm{t}$, whereas the projected weight of a 10 MW HTS generator is approximately 150-180 t [125,126]. There are several successful tests of the first generation models and the prototypes of motors and generators using HTS [127130]. In 2005, Siemens developed rotors using superconducting field windings. American Superconductor Corporation (AMSC), in collaboration with Northrop-Grumman, built the world's highest torque HTS motor for the US Navy at 36.5 MW using bismuth based superconductor (BSCCO) wire. This was delivered in 2007. The electromagnetic characteristics of a $10 \mathrm{MW}$ superconducting wind turbine generator were studied in [131]. Recently, Sway Turbine and Windtec Solutions have been developing a $10 \mathrm{MW}$ wind turbine generator, which is called the SeaTitan and this is considered to be the world's most powerful turbine [44,45]. The SeaTitan wind turbine design employs an HTS generator, which is significantly smaller and lighter and expected to be commercially available by 2015 [132]. There are several challenges, like the price of superconducting wires and cooling technology, which must be addressed before large scale utilization can be obtained.

\section{Discussion}

In terms of semiconductor technology development, a continuous race to develop highervoltage and higher-current power semiconductors, e.g. the insulated gate bipolar transistors (IGBTs), for utilization in high-power systems still goes on. Many recent generations of devices, such as 2.5, 3.3, 4.5 and $6.5 \mathrm{kV}$ IGBTs, are suitable for $2.5 \mathrm{kV}$ or lower voltage 
inverter systems with traditional 2-level topology. Although 3.3, 4.5 and $6.5 \mathrm{kV}$ IGBTs are available in the market, they are still costly. The low-voltage devices, such as $0.6,0.9,1.2$, 1.7 and $2.5 \mathrm{kV}$ IGBTs are not only mature in technology but also cheap. Therefore, the series-parallel connection of low-voltage rated semiconductors can be a cost effective solution for medium-voltage inverter applications. Multilevel converter, especially MMC topology, may be the natural choice to design medium-voltage converter using low-voltage rated devices. Recently, MMC multilevel converter has attracted significant attention to eliminate the step-up-transformer from the wind turbine nacelle. However, the MMC converter requires multiple isolated and balanced DC supplies. In this instance, multi-coil special generator, multiple traditional generators and medium-frequency common magneticlink have been proposed in recent years.

The first two solutions require special generator or multiple traditional generators, which may increase system weight, volume, complexity and cost. The recent advances in magnetic materials have led to the development of compact and light weight, medium-frequency magnetic-link, which would be a possible solution to generate multiple isolated and balanced DC supplies from a single wind turbine generator. In this context, the third solution eliminates most of the critical limitations of the first two solutions. Up to now many kinds of soft magnetic alloys with high magnetic flux density combined with low core loss have been developed. The amorphous alloy and nanocrystalline materials have excellent magnetic characteristics for medium-frequency applications, such as high permeability, high saturation flux density and relatively low core losses. With these advanced magnetic materials the medium-frequency magnetic-links have much smaller and lighter magnetic cores and windings, and much lower costs. Therefore, medium-frequency magnetic-link based mediumvoltage converter may be the natural choice to eliminate the step-up transformer from the wind turbine nacelle.

The MC provides direct AC to AC conversion, which eliminates the need for an intermediate DC conversion. However, the complexity of phase shifted multi-winding transformer or split winding PMSG may limit the voltage level of the converter. The modular converter based medium-voltage DC converter is suitable for HVDC transmission system. This converter may interconnect the wind turbine generator to the HVDC transmission line directly. The segmented stator increases the volume, weight and complexity of the wind turbine generator, which needs to be designed specially. 
Increasing the operation frequency can greatly reduce the physical volume of the transformer. The replacement of power-frequency transformer by a medium-frequency transformer could be a possible option to reduce the weight and volume of the wind turbine nacelle. However, implementation of medium-frequency medium-voltage transformer is critical, especially the insulation issue.

The mass of turbine generator is much higher than that of a turbine step-up-transformer. Generator weight reduction is the prime option to reduce the weight of wind turbine nacelle. In this instance, superconductor based generators have attracted considerable attention and become top research tropic in recent years. The estimated weight of a $5 \mathrm{MW}$ superconducting generator is only $34 \mathrm{t}$. Therefore, large weight can be reduced by replacing copper conductor generator with a superconducting generator. The recent advances in superconductor materials have led to the development of compact and light weight wind turbine generator. Still there are several challenges, like price of superconducting wires and cooling technologies which must be addressed before large scale utilization can be obtained.

\section{Conclusion}

The power rating of modern offshore wind turbine has increased up to $10 \mathrm{MW}$ in order to harvest more energy and thus reduce cost per megawatt of capacity. The construction and installation costs of these multi-megawatts turbines are really high and critical in offshore areas. The weight and volume reduction of the power generation system might be a solution to this issue.

In this context, the grid side step-up transformer-less system has drawn a high degree of attention. The medium-voltage converter may feed the wind power to the medium-voltage grid directly; without using the step-up-transformer and line filter. Medium-frequency magnetic-link-based MMC converter may be the natural choice to develop medium-voltage converter. New development of the HTS generator is another attractive solution to reduce the weight of the WTPGS. In combining these two most attractive concepts, it may be possible to design a future wind turbine, which may reduce the system weight and size as well as save large amounts of turbine construction and installation costs. Although the current research and development has brought these technologies to a certain level, more research still needs to be done to further development of power converters and turbine generators as new magnetic materials and new high-power semiconductor devices enter the market. 


\section{References}

\begin{tabular}{|c|c|}
\hline [1] & $\begin{array}{l}\text { C. Marimuthu, V. Kirubakaran. Carbon pay back period for solar and wind energy project installed in India: A } \\
\text { critical review. Renewable and Sustainable Energy Reviews 2013; 23:80-90. }\end{array}$ \\
\hline [2] & $\begin{array}{l}\text { H. Li, M. Xie and T. Zhang. Promote the development of renewable energy: A review and empirical study of wind } \\
\text { power in china. Renewable and Sustainable Energy Reviews 2013; 22:101-7. }\end{array}$ \\
\hline [3] & $\begin{array}{l}\text { B. K. Sahu, M. Hiloidhari and D. C. Baruah. Global trend in wind power with special focus on the top five wind } \\
\text { power producing countries. Renewable and Sustainable Energy Reviews 2013; 19:348-59. }\end{array}$ \\
\hline [4] & $\begin{array}{l}\text { Z. Da, Z. Xiliang, H. Jiankun and C. Qimin. Offshore wind energy development in China: Current status and } \\
\text { future perspective. Renewable and Sustainable Energy Reviews 2011; 15:4673-84. }\end{array}$ \\
\hline [5] & $\begin{array}{l}\text { J. Chen. Development of offshore wind power in China. Renewable and Sustainable Energy Reviews 2011; } \\
\text { 15:5013-20. }\end{array}$ \\
\hline [6] & $\begin{array}{l}\text { A. B. M. S. Islam, M. Jameel, M. Z. Jumaat, S. M. Shirazi and F. A. Salman. Review of offshore energy in } \\
\text { Malaysia and floating Spar platform for sustainable exploration. Renewable and Sustainable Energy Reviews } \\
\text { 2012; 16:6268-84. }\end{array}$ \\
\hline [7] & $\begin{array}{l}\text { W. Zhixin, J. Chuanwen, A. Qian and W. Chengmin. The key technology of offshore wind farm and its new } \\
\text { development in China. Renewable and Sustainable Energy Reviews 2009; 13:216-22. }\end{array}$ \\
\hline [8] & $\begin{array}{l}\text { C. P. Ion and C. Marinescu. Three-phase induction generators for single-phase power generation: An overview. } \\
\text { Renewable and Sustainable Energy Reviews 2013; 22:73-80. }\end{array}$ \\
\hline [9] & $\begin{array}{l}\text { D. Ayhan and S. Saglam. A technical review of building-mounted wind power systems and a sample simulation } \\
\text { model. Renewable and Sustainable Energy Reviews 2012; 16:1040-49. }\end{array}$ \\
\hline [10] & $\begin{array}{l}\text { M. R. Islam, S. Mekhilef and R. Saidur. Progress and recent trends of wind energy technology. Renewable and } \\
\text { Sustainable Energy Reviews 2013; 21:456-68. }\end{array}$ \\
\hline [11] & $\begin{array}{l}\text { R. L. Iglesias, R. L. Arantegui and M. A. Alonso. Power electronics evolution in wind turbines-A market-based } \\
\text { analysis. Renewable and Sustainable Energy Reviews 2011; 15:4982-93. }\end{array}$ \\
\hline [12] & $\begin{array}{l}\text { G. M. Shafiullah, A. M. T. Oo, A. B. M. S. Ali and P. Wolfs. Potential challenges of integrating large-scale wind } \\
\text { energy into the power grid-A review. Renewable and Sustainable Energy Reviews 2013; 20:306-21. }\end{array}$ \\
\hline [13] & $\begin{array}{l}\text { Z. Du and W. Gu. Aerodynamics analysis of wind power. In: Proceedings of the world non-grid-connected wind } \\
\text { power and energy conference; 2009. P. 1-3. }\end{array}$ \\
\hline [14] & $\begin{array}{l}\text { M. Islam, Y. G. Guo and J. G. Zhu. Steady state characteristic simulation of DFIG for wind power system. In: } \\
\text { Proceedings of the } 6^{\text {th }} \text { international conference on electrical and computer engineering; 2010. P. 151-4. }\end{array}$ \\
\hline [15] & $\begin{array}{l}\text { BO Wind, (March 2013). Barrow offshore wind farm non technical summary. [Online] Available at: } \\
\text { http://www.bowind.co.uk }\end{array}$ \\
\hline [16] & Observator, (January 2013). Project description. [Online] Available at: http://www.observatormeteohydro.com \\
\hline [17] & $\begin{array}{l}\text { J. R. Kristoffersen. The horns rev wind farm and the operational experience with the wind farm main controller. } \\
\text { In: Proceedings of the Copenhagen offshore wind 2005; } 2005 .\end{array}$ \\
\hline [18] & $\begin{array}{l}\text { Centrica Energy, (March 2013). Lynn and inner dowsing offshore wind farms. [Online] Available at: } \\
\text { http://www.centrica.com }\end{array}$ \\
\hline [19] & FoundOcean, (January 2013). Ormonde offshore wind farm. [Online] Available at: http://www.foundocean.com \\
\hline [20] & $\begin{array}{l}\text { Earth Policy Institute (March 2013). Climate, energy and transportation, world cumulative wind turbine } \\
\text { installations. [Online] Available at: http://www.earth-policy.org }\end{array}$ \\
\hline [21] & ergy. [Online] Availab. \\
\hline
\end{tabular}




\begin{tabular}{|c|c|}
\hline & http://www.nrel.gov \\
\hline [22] & $\begin{array}{l}\text { ABB. Wind Power Plants (January 2013). Technical application papers No. 13. [Online]. Available at: } \\
\text { http://www05.abb.com }\end{array}$ \\
\hline [23] & $\begin{array}{l}\text { J. Jeppsson, P. E. Larsen and A. Larsson, The Swedish Energy Agency, Vattenfall (January 2013). Technical } \\
\text { description Lillgrund wind power plant. [Online]. Available at: http://www.vattenfall.se }\end{array}$ \\
\hline [24] & $\begin{array}{l}\text { L. Pepper. Monitoring and evaluation of Blyth offshore wind farm- installation and commissioning (March 2013). } \\
\text { [Online]. Available at: http://webarchive.nationalarchives.gov.uk }\end{array}$ \\
\hline [25] & $\begin{array}{l}\text { G. Gerdes, A. Tiedemann, and S. Zeelenberg, (January 2013). Case study: } \square \text { Modelling offshore wind farms - a } \\
\text { survey for the analysis of the experiences and lessons learned by developers of offshore wind farms. [Online]. } \\
\text { Available at: http://www.offshore-power.net }\end{array}$ \\
\hline [26] & $\begin{array}{l}\text { M. G. Kanabar, and S. A. Khaparde. Evaluation of rotor speed stability margin of a constant speed wind turbine } \\
\text { generator. In: Proceedings of the power system technology and IEEE power India conference; 2008. P. 1-6. }\end{array}$ \\
\hline [27] & $\begin{array}{l}\text { M. G. Kanabar, C. V. Dobariya, and S. A. Khaparde. Rotor speed stability analysis of constant speed wind turbine } \\
\text { generators. In: Proceedings of the power electronics drives and energy systems; 2006. P. 1-5. }\end{array}$ \\
\hline [28] & $\begin{array}{l}\text { T. Tafticht, K. Agbossou, A. Cheriti, and M. L. Doumbia. Output power maximization of a permanent magnet } \\
\text { synchronous generator based stand-alone wind turbine. IEEE international symposium on industrial electronics; } \\
\text { 2006. P. 2412-16. }\end{array}$ \\
\hline [29] & $\begin{array}{l}\text { D. Jingya, X. Dewei, and W. Bin. A novel control system for current source converter based variable speed PM } \\
\text { wind power generators. In: Proceedings of the IEEE power electronics specialists conference; 2007. P. 1852-57. }\end{array}$ \\
\hline [30] & $\begin{array}{l}\text { A. Boyette and S. Saadate. Permanent power generating wind turbine with doubly fed asynchronous generator and } \\
\text { storage unit, modelling and simulation. In: Proceedings of the power electronics and motion control conference; } \\
\text { 2006. P. 1552-56. }\end{array}$ \\
\hline [31] & $\begin{array}{l}\text { Qihui Liu, Fang Yu and Jianhua Zhang. Novel modelling and control of doubly-fed variable-speed constant- } \\
\text { frequency wind power generator. In: Proceedings of the } 33^{\text {rd }} \text { annual conference of the IEEE industrial electronics } \\
\text { society (IECON); 2007. P. 1621-26. }\end{array}$ \\
\hline [32] & $\begin{array}{l}\text { Zhi-nong Wei, Xiao-yong Yu, Jia-jia Wu, Lian-shan Han, Xiang Xie, Dan Che, and Yue Wang. The intelligent } \\
\text { control of DFIG-based wind generation. In: Proceedings of the international conference on sustainable power } \\
\text { generation and supply; 2009. P. 1-5. }\end{array}$ \\
\hline [33] & $\begin{array}{l}\text { M. K. Das, S. Chowdhury, S. P. Chowdhury and P. A. Crossley. Doubly-fed induction generator models for } \\
\text { optimization algorithm of wind farms. In: Proceedings of the Universities power engineering conference; 2008. P. } \\
\text { 1-5. }\end{array}$ \\
\hline [34] & $\begin{array}{l}\text { M. Aktarujjaman, M. E. Haque, K. M. Muttaqi, M. Negnevitsky and G. Ledwich. Control dynamics of a doubly } \\
\text { fed induction generator under sub- and super-synchronous modes of operation. In: Proceedings of the IEEE power } \\
\text { and energy society general meeting - conversion and delivery of electrical energy in the } 21^{\text {st }} \text { century; 2009. P. 1-9. }\end{array}$ \\
\hline [35] & $\begin{array}{l}\text { Paul C. Roberts. A study of brushless double-fed (induction) machines. PhD thesis, Emmanuel College, University } \\
\text { of Cambridge; } 2005 .\end{array}$ \\
\hline [36] & $\begin{array}{l}\text { Youguang Guo, Xuefan Wang, Jian Guo Zhu and Haiyan Lu. Development of a wound rotor brushless doubly fed } \\
\text { machine based on slot MMF harmonics. In: Proceedings of the IEEE industry applications society annual meeting; } \\
\text { 2008. P. 1-5. }\end{array}$ \\
\hline [37] & $\begin{array}{l}\text { R. Carlson, H. Voltolini, F. Runcos, P. Kuo-Peng, and N. J. Batistela. Performance analysis with power factor } \\
\text { compensation of a } 75 \mathrm{~kW} \text { brushless doubly fed induction generator prototype. In: Proceedings of the IEEE electric } \\
\text { machines \& drives conference; 2007. P. 1502-07. }\end{array}$ \\
\hline [38] & F. Riincos, R. Carlson, N. Sadowski, P. Kuo-Peng, and H. Voltolini. Performance and vibration analysis of a 75 \\
\hline
\end{tabular}




\begin{tabular}{|c|c|}
\hline & $\begin{array}{l}\text { kW brushless double-fed induction generator prototype. In: Proceedings of the IEEE industry applications } \\
\text { conference; 2006. P. 2395-2402. }\end{array}$ \\
\hline [39] & $\begin{array}{l}\text { Yong Liu, Lingzhi Yi, and Xiaoyun Zhao. Control of brushless doubly-fed machine for wind power generation } \\
\text { based on two-stage matrix converter. In: Proceedings of the Asia-Pacific power and energy engineering } \\
\text { conference; 2009. P. 1-5. }\end{array}$ \\
\hline [40] & $\begin{array}{l}\text { D. Zhou and R. Spee. Field oriented control development for brushless doubly-fed machines. In: Proceedings of } \\
\text { the IEEE } 31^{\text {st }} \text { IAS annual conference; 1996. P. 304-10. }\end{array}$ \\
\hline [41] & $\begin{array}{l}\text { F. Poitiers, T. Bouaouiche, and M. Machmoum. Advanced control of a doubly-fed induction generator for wind } \\
\text { energy conversion. Electric Power Systems Research 2009; p. 1085-96. }\end{array}$ \\
\hline [42] & $\begin{array}{l}\text { I. M. D. Alegria, J. L. Martin, I. Kortabarria, J. Andreu and P. I. Ereno. Transmission alternatives for offshore } \\
\text { electrical power. Renewable and Sustainable Energy Reviews 2009; 13:1027-38. }\end{array}$ \\
\hline [43] & ENERCON (March 2013). E126/7500 stat of the art. [Online] Available at: http://www.enercon.de \\
\hline [44] & $\begin{array}{l}\text { ENERCON (March 2013). Sway pushes ahead with } 10 \mathrm{MW} \text { offshore/onshore turbine. [Online] Available at: } \\
\text { http://www.swayturbine.no }\end{array}$ \\
\hline [45] & AMSC (March 2013). SeaTitan 10 MW wind turbine. [Online] Available at: http://www.amsc.com \\
\hline [46] & AMSC (March 2013). Wt5500df and wt5500fc. [Online] Available at: http://www.amsc.com \\
\hline [47] & $\begin{array}{l}\text { Renewables International (April 2012). Wind turbines, windenergieanlagen 2012. [Online] Available at: } \\
\text { http://www.wind-turbine-market.de }\end{array}$ \\
\hline [48] & GE Energy (January 2013). GE 1.5 SLE turbine specifications. [Online] Available at: http://www. Iprcanada.com \\
\hline [49] & $\begin{array}{l}\text { Repower Systems (January 2013). } \text { Repower MM92, product description. [Online] Available at: } \\
\text { https://www.edockets.state.mn.us }\end{array}$ \\
\hline [50] & $\begin{array}{l}\text { L. H. Hansen, L. Helle, F. Blaabjerg, E. Ritchie, S. Munk- Nielsen, H. Bindner, P. Sørensen and B. Bak-Jensen. } \\
\text { Conceptual survey of generators and power electronics for wind turbines. Risø National Laboratory, Roskilde, } \\
\text { Denmark; } 2001 \text {. }\end{array}$ \\
\hline [51] & $\begin{array}{l}\text { Anca D. Hansen. Generators and power electronics for wind turbines. In: Wind power in power systems, John } \\
\text { Wiley \& Sons Ltd; } 2005 .\end{array}$ \\
\hline [52] & L. L. Lai, and T. F. Chan. Distributed generation, IEEE press, John Wiley \& Sons Ltd; 2007. \\
\hline [53] & $\begin{array}{l}\text { A. Petersson. Analysis, Modeling and control of doubly-fed induction generators for wind turbines. PhD } \\
\text { dissertation, Chalmers University of Technology, Sweden; } 2005 \text {. }\end{array}$ \\
\hline [54] & $\begin{array}{l}\text { J. Chai, Z. Zhang. Calculation of equivalent circuit parameters of doubly-fed induction generator based on } \\
\text { magnetic field finite element analysis. In: Proceedings of the international conference on electrical machines and } \\
\text { systems; 2008. P. 3767-71. }\end{array}$ \\
\hline [55] & L. J. Hunt. A new type of induction motor. Journal of the Institution of Electrical Engineers 1907; 39:648-67. \\
\hline [56] & $\begin{array}{l}\text { F. Creedy. Some developments in multi-speed cascade induction motors. Journal of the Institution of Electrical } \\
\text { Engineers 1921; 59:511-32. }\end{array}$ \\
\hline [57] & $\begin{array}{l}\text { B. H. Smith. Theory and performance of a twin stator induction machine. IEEE Transactions on Power Apparatus } \\
\text { and Systems 1966; PAS-85:123-31. }\end{array}$ \\
\hline [58] & $\begin{array}{l}\text { A. R. W. Broadway, L. Burbridge. Self-cascaded machine: a low-speed motor or high-frequency brushless } \\
\text { alternator. Proceedings of the Institution of Electrical Engineers 1970; 117:1277-90. }\end{array}$ \\
\hline [59] & $\begin{array}{l}\text { F. Shibata, K. Taka. Speed control system for brushless cascade induction motors in control range of slips s1>1 } \\
\text { and S2>1. IEEE Transactions on Energy Conversion 1987; EC-2:246-53. }\end{array}$ \\
\hline [60] & $\begin{array}{l}\text { W. Fengxiang, Z. Fengge, X. Longya. Parameter and performance comparison of doubly fed brushless machine } \\
\text { with cage and reluctance rotors. IEEE Transactions on Industry Applications 2002; 38:1237-43. }\end{array}$ \\
\hline
\end{tabular}




\begin{tabular}{|c|c|}
\hline [61] & $\begin{array}{l}\text { K. Wallace, R. Spee, H. K. Lauw. Dynamic } \square \text { odelling of brushless doubly-fed machines. In: Proceedings of the } \\
\text { EE industry applications society annual meeting; 1989. P. 329-34. }\end{array}$ \\
\hline [62] & $\begin{array}{l}\text { P. Rochelle, R. Spee, A. K. Wallace. The effect of stator winding configuration on the performance of brushless } \\
\text { doubly-fed machines in adjustable speed drives. In: Proceedings of the IEEE industry applications society annual } \\
\text { meeting; 1990. P. 331-37. }\end{array}$ \\
\hline [63] & $\begin{array}{l}\text { G. C. Alexander. Characterization of the brushless, doubly-fed machine by magnetic field analysis. In: } \\
\text { Proceedings of the IEEE industry applications society annual meeting; 1990. P. 67-74. }\end{array}$ \\
\hline [64] & $\begin{array}{l}\text { R. Li, A. Wallance, R. Spee, Y. Wang. Two-axis model development of cage-rotor brushless doubly-fed machines. } \\
\text { IEEE Transactions on Energy Conversion 1991; 6:453-60. }\end{array}$ \\
\hline [65] & $\begin{array}{l}\text { R. Li, A. Wallace, R. Spee. Dynamic simulation of brushless doubly-fed machines. IEEE Transactions on Energy } \\
\text { Conversion 1991; 6:445-52. }\end{array}$ \\
\hline [66] & $\begin{array}{l}\text { S. Williamson, A. C. Ferreira, A. K. Wallace. Generalised theory of the brushless doubly-fed machine. I. analysis. } \\
\text { IEE Proceedings of Electric Power Applications 1997; 144:111-22. }\end{array}$ \\
\hline [67] & $\begin{array}{l}\text { R. A. McMahon, P. C. Roberts, X. Wang, P. J. Tavner. Performance of BDFM as generator and motor. IEE } \\
\text { Proceedings of Electric Power Applications 2006; 153:289-99. }\end{array}$ \\
\hline [68] & $\begin{array}{l}\text { P. J. Tavner, M. Jagiela, T. Chick, E. Abdi-Jalebi. A brushless doubly fed machine for use in an integrated } \\
\text { motor/converter, considering the rotor flux. In: Proceedings of the } 3^{\text {rd }} \text { IET international conference on power } \\
\text { electronics, machines and drives; 2006. P. 601-05. }\end{array}$ \\
\hline [69] & $\begin{array}{l}\text { X. Wang, P. C. Roberts, R. A. McMahon. Optimisation of BDFM stator design using an equivalent circuit model } \\
\text { and a search method. In: Proceedings of the } 3^{\text {rd }} \text { IET international conference on power electronics, machines and } \\
\text { drives; 2006. P. } 606-10 \text {. }\end{array}$ \\
\hline [70] & $\begin{array}{l}\text { X. Wang, R. A. McMahon, P. J. Tavner. Design of the brushless doubly-fed (induction) machine. In: Proceedings } \\
\text { of the IEEE international electric machines \& drives conference; 2007. P. 1508-1513. }\end{array}$ \\
\hline [71] & $\begin{array}{l}\text { D. Xianming, T. Guojun , X. Zhang, M. Zhixun. Structure research and design of brushless doubly-fed machine. } \\
\text { In: Proceedings of the Asia-pacific power and energy engineering conference; 2009. P. 1-4. }\end{array}$ \\
\hline [72] & $\begin{array}{l}\text { E. M. Schulz, R. E. Betz. Optimal rotor design for brushless doubly fed reluctance machines. In: Proceedings of } \\
\text { the } 38^{\text {th }} \text { IAS annual meeting industry applications conference; 2003. P. 256-261. }\end{array}$ \\
\hline [73] & $\begin{array}{l}\text { K. Chaohao, W. Xuefan, X. Fei, Z. Jingwei, W. Tao and T. Huawei. Design optimization of tooth-harmonic } \\
\text { brushless doubly-fed machine. In: Proceedings of the international conference on electrical machines and systems; } \\
\text { 2008. P. 4272-76. }\end{array}$ \\
\hline [74] & $\begin{array}{l}\text { F. Zhang, G. Pan, F. Wang and M. Lin. Study on design of brushless doubly-fed machine with a new type rotor. } \\
\text { In: Proceedings of the IEEE international conference on industrial technology; 2009. P. 1-3. }\end{array}$ \\
\hline [75] & $\begin{array}{l}\text { F. Blazquez, C. Veganzones, D. Ramirez, and C. Platero. Characterization of the rotor magnetic field in a } \\
\text { brushless doubly-fed induction machine. IEEE Transactions on Energy Conversion 2009; 24:599-607. }\end{array}$ \\
\hline [76] & ABB (March 2013). Distribution transformer. [Online]. Available at: http://www.coronabd.com \\
\hline [77] & ABB. (January 2013). Liquid-filled transformer. [Online]. Available at: http://www05.abb.com \\
\hline [78] & $\begin{array}{l}\text { Pauwels SLIM Transformer (January 2013). SLIM transformer inside the world’s highest wind turbine. [Online]. } \\
\text { Available at: http://www. Pauwels.com. }\end{array}$ \\
\hline [79] & $\begin{array}{l}\text { M. J. Kaiser and B. Snyder, Energy Research Group, LLC Baton Rough, Louisiana (January 2013). Offshore wind } \\
\text { energy installation and decommissioning cost estimation in the U.S. outer continental shelf. [Online]. Available at: } \\
\text { http://www.boemre.gov }\end{array}$ \\
\hline [80] & $\begin{array}{l}\text { O. Keysan and A. Mueller A homopolar HTSG topology for large direct-drive wind turbines. IEEE Transactions } \\
\text { on Applied Superconductivity 2011; 21(5): 3523-31. }\end{array}$ \\
\hline
\end{tabular}




\begin{tabular}{|c|c|}
\hline [81] & $\begin{array}{l}\text { J. S. Lai and F. Z. Peng. Multilevel converters-a new breed of power converters. IEEE Transactions on Industry } \\
\text { Applications 1996; 32:509-517. }\end{array}$ \\
\hline [82] & $\begin{array}{l}\text { A. Nabae, I. Takahashi and H. Akagi. A new neutral-point-clamped PWM inverter. IEEE Transactions on Industry } \\
\text { Applications 1981; 17:518-523. }\end{array}$ \\
\hline [83] & $\begin{array}{l}\text { F. Z. Peng, J. S. Lai, J. McKeever and J. VanCoevering, “A multilevel voltage source inverter with separate DC } \\
\text { sources for static VAR generation,” IEEE Transactions on Industry Applications 1996; 32:1130-38. }\end{array}$ \\
\hline [84] & $\begin{array}{l}\text { M. R. Islam, Y. Guo, J. G. Zhu and D. Dorrell. Design and comparison of } 11 \mathrm{kV} \text { multilevel voltage source } \\
\text { converters for local grid based renewable energy systems. In: Proceedings of the } 37^{\text {th }} \text { annual conference of the } \\
\text { IEEE industrial electronics society (IECON 2011); 2011. P. 3596-3601. }\end{array}$ \\
\hline [85] & $\begin{array}{l}\text { D. Zhong, B. Ozpineci, L. M. Tolbert, and J. N. Chiasson. DC-AC cascaded H-bridge multilevel boost inverter } \\
\text { with no inductors for electric/hybrid electric vehicle applications. IEEE Transactions on Industry Applications } \\
\text { 2009; 45:963-970. }\end{array}$ \\
\hline [86] & $\begin{array}{l}\text { S. S. Geun, K. F. Soon, and P. S. Jun. Cascaded multilevel inverter employing three-phase transformers and } \\
\text { single DC input. IEEE Transactions on Industrial Electronics 2009; 56:2005-14. }\end{array}$ \\
\hline [87] & $\begin{array}{l}\text { E. Spooner, P. Gordon, J. R. Bumby and C. D. French. Lightweight ironless-stator PM generators for direct-drive } \\
\text { wind turbines. IEE Proceedings of Electric Power Applications 2005; 152:17-26. }\end{array}$ \\
\hline [88] & $\begin{array}{l}\text { M. A. Parker, C. H. Ng, L. Ran, P. Tavner and E. Spooner. Power control of direct drive wind turbine with } \\
\text { simplified conversion stage \& transformerless grid interface. In: Proceedings of the } 41^{\text {st }} \text { International Universities } \\
\text { Power Engineering Conference; 2006. P. 65-68. }\end{array}$ \\
\hline [89] & $\begin{array}{l}\text { J. M. Carrasco, L. G. Franquelo, J. T. Bialasiewicz, E. Galvan, R. C. P. Guisado, Ma. A. M. Prats, J. I. Leon and } \\
\text { N. Moreno-Alfonso. Power-electronic systems for the grid integration of renewable energy sources: a survey. } \\
\text { IEEE Transactions on Industrial Electronics 2006; 53:1002-16. }\end{array}$ \\
\hline [90] & $\begin{array}{l}\text { C. H. Ng, M. A. Parker, Li Ran, P. J. Tavner, J. R. Bumby and E. Spooner. A multilevel modular converter for a } \\
\text { large, light weight wind turbine generator. IEEE Transactions on Power Electronics 2008; 23:1062-74. }\end{array}$ \\
\hline [91] & $\begin{array}{l}\text { X. Yuan, Y. Li, J. Chai and M. Ma. A modular direct-drive permanent magnet wind generator system eliminating } \\
\text { the grid-side transformer In: Proceedings of the } 13^{\text {th }} \text { European conference on power electronics and applications; } \\
\text { 2009. P. 1-7. }\end{array}$ \\
\hline [92] & $\begin{array}{l}\text { X. Yuan, J. Chai and Y. Li. A transformer-less high-power converter for large permanent magnet wind generator } \\
\text { systems. IEEE Transactions on Sustainable Energy 2012; 3:318-329. }\end{array}$ \\
\hline [93] & $\begin{array}{l}\text { F. Deng and Z. Chen. A new structure based on cascaded multilevel converter for variable speed wind turbine. In: } \\
\text { Proceedings of the } 36^{\text {th }} \text { annual conference on IEEE industrial electronics Society; 2010. P. 3167-72. }\end{array}$ \\
\hline [94] & $\begin{array}{l}\text { M. R. Islam, Y. G. Guo, and J. G. Zhu. A transformer-less compact and light wind turbine generating system for } \\
\text { offshore wind farms. In: Proceedings of the } 2012 \text { IEEE international conference on power and energy; 2012. P. } \\
605-10 .\end{array}$ \\
\hline [95] & $\begin{array}{l}\text { M. R. Islam, Y. G. Guo, and J. G. Zhu, "A high-frequency link modular multilevel cascaded medium voltage } \\
\text { converter for direct grid integration of renewable energy systems," IEEE Transactions on Power Electronics, DOI: } \\
\text { 10.1109/TPEL.2013.2290313. }\end{array}$ \\
\hline [96] & $\begin{array}{l}\text { M. R. Islam, Y. G. Guo, and J. G. Zhu, "H-bridge multilevel voltage source converter for direct grid connection of } \\
\text { renewable energy systems,” In: Proceedings of } 2011 \text { IEEE Power \& Energy Society Innovative Smart Grid } \\
\text { Technologies Asia (ISGT2011), 13-16 November 2011, Perth, Australia, p. 1-7. }\end{array}$ \\
\hline [97] & $\begin{array}{l}\text { M. R. Islam, Y. G. Guo, and J. G. Zhu. A medium frequency transformer with multiple secondary windings for } \\
\text { medium voltage converter based wind turbine power generating systems. Journal of Applied Physics 2013; } \\
\text { 113:17A324-26. }\end{array}$ \\
\hline
\end{tabular}




\begin{tabular}{|c|c|}
\hline [98] & $\begin{array}{l}\text { M. R. Islam, Y. G. Guo, and J. G. Zhu, “A medium-frequency transformer with multiple secondary windings for } \\
\text { grid connection through H-bridge voltage source converters,” In: Proceedings of International Conference on } \\
\text { Electrical Machines and Systems, 21-24 October 2012, Sapporo, Japan, pp. 1-6. }\end{array}$ \\
\hline [99] & $\begin{array}{l}\text { M. R. Islam, Y. G. Guo, Z. W. Lin, and J. G. Zhu, An amorphous alloy core medium frequency magnetic-link for } \\
\text { medium voltage PV inverters. Journal of Applied Physics, Article in press. }\end{array}$ \\
\hline [100] & $\begin{array}{l}\text { A. Alesina and M. G. B. Venturini. Analysis and design of optimum-amplitude nine-switch direct AC-AC } \\
\text { converters. IEEE Transactions on Power Electronics 1989; 4:101-12. }\end{array}$ \\
\hline [101] & $\begin{array}{l}\text { P. W. Wheeler, J. Rodriguez, J. C. Clare, L. Empringham and A. Weinstein. Matrix converters: a technology } \\
\text { review. IEEE Transactions on Industrial Electronics 2002; 49:276-88. }\end{array}$ \\
\hline [102] & $\begin{array}{l}\text { P. Wheeler, L. Xu, M. Y. Lee, L. Empringham, C. Klumpner and J. Clare. A review of multi-level matrix } \\
\text { converter topologies. In: Proceedings of the } 4^{\text {th }} \text { IET conf. on power elec., mach. And drives; 2008. 286-90. }\end{array}$ \\
\hline [103] & $\begin{array}{l}\text { A. Djahbar, B. Mazari and M. Latroch. Control strategy of three-phase matrix converter fed induction motor drive } \\
\text { system. In: Proceedings of the IEEE int. work. On intell. Signal proc.; 2005. 104-9. }\end{array}$ \\
\hline [104] & $\begin{array}{l}\text { J. W. Kolar, F. Schafmeister, S. D. Round and H. Ertl. Novel three-phase AC-AC sparse matrix converters. IEEE } \\
\text { Transactions on Power Electronics 2007; 22:1649-61. }\end{array}$ \\
\hline [105] & $\begin{array}{l}\text { E. Yamamoto, H. Hara, T. Uchino, M. Kawaji, T. J. Kume, J. K. Kang and H. P. Krug. Development of MCs and } \\
\text { its applications in industry. IEEE Industrial Electronics Magazine 2011; 5:4-12. }\end{array}$ \\
\hline [106] & $\begin{array}{l}\text { J. Change. Modular AC-AC variable voltage and variable frequency power converter system and control. US } \\
\text { Patent } 5909 \text { 367; } 1999 .\end{array}$ \\
\hline [107] & $\begin{array}{l}\text { T. F. Podlesak, D. C. Katsis, P. W. Wheeler, J. C. Clare, L. Empringham, and M. A. Bland, “150-kVA vector- } \\
\text { controlled matrix converter induction motor drive,” IEEE Transactions on Industry Applications, vol. 41, no. , pp. } \\
\text { 3, 841-847, May } 2005 .\end{array}$ \\
\hline [108] & $\begin{array}{l}\text { Y. Ueda, M Ikeda, R. Suenaga, K. Imanishi, E. Masuda and E. Watanabe. Development of medium voltage matrix } \\
\text { converter In: Proceedings of the IEEJ Annual Meeting; } 2007 .\end{array}$ \\
\hline [109] & $\begin{array}{l}\text { M. Swamy and T. Kume. Present state and a futuristic vision of motor drive technology. In: Proceedings of the } \\
11^{\text {th }} \text { international conference on OPTIM; 2008. p. XLV-LVI. }\end{array}$ \\
\hline [110] & $\begin{array}{l}\text { J. Kang, E. Yamamoto, M. Ikeda and E. Watanabe. Medium-voltage matrix converter design using cascaded } \\
\text { single-Phase power cell modules. IEEE Transactions on Industrial Electronics 2011; 58:5007-13. }\end{array}$ \\
\hline [111] & $\begin{array}{l}\text { J. Wang, B. Wu, D. Xu and N. R. Zargari. Multimodular matrix converters with sinusoidal input and output } \\
\text { waveforms. IEEE Transactions Industrial Electronics 2012; 59:17-26. }\end{array}$ \\
\hline [112] & $\begin{array}{l}\text { J. Kang, N. Takada, E. Yamamoto and E. Watanabe. High power matrix converter for wind power generation } \\
\text { applications. In: Proceedings of the } 2011 \text { IEEE 8th international conference on power electronics (ECCE Asia); } \\
\text { 2011. p. 1331-36. }\end{array}$ \\
\hline [113] & $\begin{array}{l}\text { S. D. G. Jayasinghe and D. M. Vilathgamuwa. A modular matrix converter for transformer-less PMSG wind } \\
\text { generation systems. In: Proceedings of the } 2011 \text { IEEE 9th international conference on power electronics and drive } \\
\text { systems (PEDS); 2011. p. 474-79. }\end{array}$ \\
\hline [114] & $\begin{array}{l}\text { P. K. Olsen, S. Gjerde, R. M. Nilssen, J. Hoelto and S. Hvidsten. A Transformer-less generator-converter concept } \\
\text { making feasible a } 100 \mathrm{kV} \text { light weight offshore wind turbine: Part I - The generator. In: Proceedings of the } 2012 \\
\text { IEEE energy conversion congress and exposition (ECCE); 2012. p. 247-52. }\end{array}$ \\
\hline [115] & $\begin{array}{l}\text { S. S. Gjerde, P. K. Olsen and T. M. Undeland. A transformer-less generator-converter concept making feasible a } \\
100 \mathrm{kV} \text { low weight offshore wind turbine Part II - The converter. In: Proceedings of the } 2012 \text { IEEE energy } \\
\text { conversion congress and exposition (ECCE); 2012. p. 253-60. }\end{array}$ \\
\hline [116] & R. A. Friedemann, F. Krismer and J. W. Kolar. Desig \\
\hline
\end{tabular}




\begin{tabular}{|c|c|}
\hline & $\begin{array}{l}\text { irborne Wind Turbine system. In: Proceedings of the 27th annual IEEE applied power electronic conference and } \\
\text { xposition (APEC); 2012. p. 509-516. }\end{array}$ \\
\hline [117] & $\begin{array}{l}\text { A. Prasai, J. S. Yim, D. Divan, A. Bendre and S. K. Sul. A new architecture for offshore wind farms. IEEE } \\
\text { Transactions on Power Electronics 2008; 23:1198-1204. }\end{array}$ \\
\hline [118] & $\begin{array}{l}\text { M Sabahi, A. Y. Goharrzi, S. H. Hosseini, M. B. B. Sharifian and G. B. Gharehpetian. Flexible power electronic } \\
\text { transformer. IEEE Transactions on Power Electronics 2010; 25:2159-69. }\end{array}$ \\
\hline [119] & $\begin{array}{l}\text { S. Meier, S. Norrga and H. P. Nee. New topology for more efficient AC/DC converters for future offshore wind } \\
\text { farms. In: Proceedings of the } 4^{\text {th }} \text { Nordic workshop on power and industrial electronics; } 2004 \text {. }\end{array}$ \\
\hline [120] & $\begin{array}{l}\text { A. Prasai, A. Bendre, J. S. Yim; S. K. Sul, D. Divan and F. Kreikebaum. A new architecture for offshore wind } \\
\text { farms. In: Proceedings of the } 2007 \text { European conference on power electronics and applications; 2007. p. 1-10. }\end{array}$ \\
\hline [121] & $\begin{array}{l}\text { S. Meier, T. Kjellqvist, S. Norrga and H. P. Nee. Design considerations for medium-frequency power transformers } \\
\text { in offshore wind farms. In: Proceedings of the 13th European conference on power electronics and applications; } \\
\text { 2009. p. 1-12. }\end{array}$ \\
\hline [122] & $\begin{array}{l}\text { A. Garcés and M. Molinas. High frequency wind energy conversion from the ocean. In: Proceedings of the } 2010 \\
\text { international power electronics conference (IPEC); 2010. p. 2056-61. }\end{array}$ \\
\hline [123] & $\begin{array}{l}\text { J. H. Parker and R. A. Towne. Design of large superconducting turbine generators for electric utility application. } \\
\text { IEEE Transactions on Power Applications and Systems 1979; PAS-98:2241-2250. }\end{array}$ \\
\hline [124] & $\begin{array}{l}\text { S. Minnich, T. Keim, M. Chari, B. Gamble, M. Jefferies, D. Jones, E. Laskaris and P. Rios. Design studies of } \\
\text { superconducting generators. IEEE Transactions Magnetics 1979; 15:703-10. }\end{array}$ \\
\hline [125] & $\begin{array}{l}\text { H. Li, Z. Chen and H. Polinder. Optimization of multibrid permanent-magnet wind generator systems. IEEE } \\
\text { Transactions on Energy Conversion 2009; 24:82-92. }\end{array}$ \\
\hline [126] & $\begin{array}{l}\text { G. Snitchler. Progress on high temperature superconductor propulsion motors and direct drive wind generators. In: } \\
\text { Proceedings of the } 2010 \text { international power electronics conference (IPEC); 2010. p. 5-10. }\end{array}$ \\
\hline [127] & $\begin{array}{l}\text { D. Aized, B. B. Gamble, A. Sidi-Yekhlef, J. P. Voccio, D. I. Driscoll, B. A. Shoykhet, and B. X. Zhang. Status of } \\
\text { the } 1000 \text { HP HTS motor development. IEEE Transactions on Applied Superconductivity 1999; 9:1197-1200. }\end{array}$ \\
\hline [128] & $\begin{array}{l}\text { D. Driscoll, V. Dombrovski and B. Zhang. Development status of superconducting motors. IEEE Power } \\
\text { Engineering Review 2000; 20:12-15. }\end{array}$ \\
\hline [129] & $\begin{array}{l}\text { B. B. Gamble, S. Kalsi, G. Snitchler, D. Madura and R. Howard. The status of HTS motors. In: Proceedings of the } \\
2002 \text { IEEE power engineering society summer meeting; 2002. p. 270-74. }\end{array}$ \\
\hline [130] & $\begin{array}{l}\text { M. Frank, J. Frauenhofer, P. van Hasselt, W. Nick, H. W. Neumueller and G. Nerowski. Long-term operational } \\
\text { experience with first Siemens } 400 \mathrm{~kW} \text { HTS machine in diverse configurations. IEEE Transactions on Applied } \\
\text { Superconductivity 2003; 13:2120-23. }\end{array}$ \\
\hline [131] & $\begin{array}{l}\text { H. Ohsaki, Y. Terao, R. M. Quddes and M. Sekino. Electromagnetic characteristics of } 10 \text { MW class } \\
\text { superconducting wind turbine generators. In: Proceedings of the } 2010 \text { international conference on electrical } \\
\text { machines and systems (ICEMS); 2010. p. 1303-06. }\end{array}$ \\
\hline [132] & $\begin{array}{l}\text { G. Snitchler, B. Gamble, C. King and P. Winn. } 10 \text { MW class superconductor wind turbine generators. IEEE } \\
\text { Transactions on Applied Superconductivity 2011; 21:1089-92. }\end{array}$ \\
\hline
\end{tabular}

